The Canadian Mineralogist

Vol. 40, pp. 67-83 (2002)

\title{
POLYMETAMORPHIC AMPHIBOLE VEINS IN METABASALTS FROM THE BETIC OPHIOLITIC ASSOCIATION AT CÓBDAR, SOUTHEASTERN SPAIN: RELICS OF OCEAN-FLOOR METAMORPHISM PRESERVED THROUGH THE ALPINE OROGENY
}

\author{
ENCARNACIÓN PUGA ${ }^{\S}$ \\ Instituto Andaluz de Ciencias de la Tierra (CSIC-UGRA), Facultad de Ciencias, \\ Universidad de Granada, Avda. Fuentenueva, s/n, E-18002 Granada, Spain \\ Maria Dolores RUIZ CRUZ \\ Departamento de Química Inorgánica, Cristalografía y Mineralogía, Facultad de Ciencias, \\ Universidad de Málaga, Campus de Teatinos, E-29071 Málaga, Spain \\ Antonio DÍAZ De FEDERICO \\ Departamento de Mineralogía y Petrología, Facultad de Ciencias, \\ Universidad de Granada, Avda. Fuentenueva, s/n, E-18002 Granada, Spain
}

\begin{abstract}
Our aim in this work is (1) to characterize mineralogically and geochemically the brown amphibole and other minerals filling millimetric veins in the Cóbdar metabasalts of the Betic ophiolites in southern Spain, and (2) to deduce their genetic conditions, mainly with the aid of the optical microscopy and analytical electron-microprobe analysis, complemented by transmission and analytical electron microscopy. The vein-filling minerals can be grouped into two assemblages according to their textural relationships. The first assemblage comprises brown amphibole (titanian pargasite and kaersutite) and sodic-calcic plagioclase, and the second one comprises green amphibole (mainly katophorite, barroisite, taramite and tremolite), sodic plagioclase, rutile, clinozoisite and calcite. Brown and green amphiboles present similar, unusually high chlorine contents, up to 0.8 wt. $\%$. Halite micro-inclusions are present in the brown amphiboles, whereas chlorine is incorporated in the structure of the green sodic-calcic amphiboles. Differences in $\mathrm{Ti},{ }^{\mathrm{IV}} \mathrm{Al},{ }^{\mathrm{VI}} \mathrm{Al}$ and ${ }^{B} \mathrm{Na}$ values between the brown and green amphiboles clearly indicate different genetic conditions, which are, in turn, similar to those corresponding to amphiboles developed in ocean-floor and orogenic metamorphic conditions, respectively. P-T estimates yield temperatures ranging from $660^{\circ}$ to $880^{\circ} \mathrm{C}$ at very low pressure for the first assemblage, and conditions lower than $550^{\circ} \mathrm{C}$ and $8 \mathrm{kbar}$ for the second assemblage. These data suggest that the minerals filled the Cóbdar veins during the pre-Alpine ocean-floor metamorphic stage (dated by ${ }^{40} \mathrm{Ar} /{ }^{39} \mathrm{Ar}$ laser probe on brown amphibole as Upper Jurassic), and were re-equilibrated under conditions of the albite-epidote amphibolite facies during the Alpine orogeny.
\end{abstract}

Keywords: polymetamorphic amphibole veins, chlorine in amphibole, ophiolitic metabasalts, Jurassic ocean-floor metamorphism, Alpine orogeny, Betic Ophiolitic Association, Mulhacén Complex, Spain.

\section{SOMMAIRE}

Le but de ce travail est de caractériser minéralogiquement et géochimiquement l'amphibole brune et les autres minéraux remplissant des veines millimétriques recoupant les métabasaltes de Cóbdar, ceinture ophiolitique bétique, dans le sud de l'Espagne, et d'en déduire leurs conditions de genèse en utilisant principalement la microscopie optique et la microsonde électronique analytique (EMPA), complétées par la microscopie électronique par transmission (TEM, AEM). Les divers minéraux remplissant ces veines peuvent être regroupés en deux paragenèses, en fonction de leurs relations texturales. La première paragenèse est formée d'amphibole brune (pargasite titanifère et kaersutite) et plagioclase sodi-calcique; la seconde est faite d'amphibole verte (surtout kataphorite, barroisite, taramite et trémolite), plagioclase sodique, rutile, clinozoïsite et calcite. Les amphiboles brunes et vertes présentent des contenus similaires en chlore, jusqu'à $0,8 \%$ en poids. Cet élément, selon les observations au TEM et les considérations cristallographiques, forme des micro-inclusions de halite dans les amphiboles brunes, tandis qu'il est incorporé dans le réseau des amphiboles vertes sodi-calciques. Les différences en teneurs en $\mathrm{Ti}$, ${ }^{\mathrm{IV}} \mathrm{Al}$, ${ }^{\mathrm{VI}} \mathrm{Al}$ et ${ }^{B} \mathrm{Na}$ entre

$\S \quad$ E-mail address: epuga@goliat.ugr.es 
les amphiboles brunes et vertes indiquent clairement, pour ces deux types, des conditions physiques de genèse différentes qui, à leur tour, sont semblables a celles des amphiboles formées, les premières dans des conditions de métamorphisme de fond océanique, les secondes dans des conditions orogéniques. L'équilibre amphibole-plagioclase, ainsi que les estimés de P-T pour les métabasaltes contenant les veines d'amphibole, indiquent une température entre $660^{\circ}$ et $880^{\circ} \mathrm{C}$ à très basse $\mathrm{P}$ pour le première paragenèse, et moins de $550^{\circ} \mathrm{C}$ et $8 \mathrm{kbar}$ pour la seconde. Les minéraux remplissant les veines de Cóbdar ont donc commencé à se développer lors d'un stade métamorphique pré-alpin de fond océanique (daté comme Jurassique supérieur par sonde laser ArAr sur des amphiboles brunes); ils ont par la suite ré-équilibré à des conditions du faciès amphibolite à albite-épidote durant l'orogenèse alpine.

Mots-clés: veines polymétamorphiques d'amphibole, chlore dans l'amphibole, métabasaltes ophiolitiques, métamorphisme de fond océanique Jurassique, orognèse alpine, association ophiolitique Bétique, complexe du Mulhacén, Espagne.

\section{INTRODUCTION}

The various igneous rocks comprising the Betic Ophiolitic Association (BOA) of the Mulhacén Complex in southern Spain, as defined by Puga (1990), preserve chemical and mineralogical evidence of a pre-Alpine stage of metasomatic and metamorphic transformation developed in an ocean-floor environment. During this episode, both gabbros and basalts of this association were the site of high-geothermal-gradient metamorphic assemblages in the amphibolite and greenschist facies (Puga et al. 1989a, 1999a). Most of these assemblages were transformed during the Alpine orogenic metamorphism into eclogite and rocks of the albite-epidote amphibolite facies, with low and intermediate geothermal gradients, respectively (Puga et al. 2000). Likewise, the ultramafic BOA rocks and the dykes intruded in them underwent an initial stage of serpentinization and rodingitization in an oceanic environment, prior to the transformations characterizing the Alpine metamorphism (Puga et al. 1999b).

In the Cóbdar region, the BOA comprises several lenticular outcrops, several $\mathrm{km}$ in length and several hundred meters thick, of metabasic and metasedimentary rock (Fig. 1). These outcrops contain a plutonic sequence consisting of troctolitic cumulates, olivinepyroxene gabbros and dolerites, cut by numerous dykes of porphyritic basalt and a volcanic sequence composed of massive or vesicular metabasalts, which are sporadically intersected by basaltic dykes and contain local pillow-structures. The volcanic and plutonic sequences of Cóbdar are overlain by a sequence of metasedimentary rocks, similar to that covering the Alpine ophiolites (Lagabrielle et al. 1984, Deville et al. 1992). These rocks contain relics of foraminifera of probable Cretaceous age (Tendero et al. 1993), similar to those determined by Lemoine et al. (1984) in the Western Alps.

The Cóbdar metabasic rocks (Almería Province) preserve much better than elsewhere assemblages typical of ocean-floor metamorphism as well as relics of the pre-existing igneous assemblages. The ophiolitic association is discontinuously exposed along about $250 \mathrm{~km}$ in the Mulhacén Complex (black dots in Fig. 1). Within the assemblage of ocean-floor metamorphism, the most characteristic mineral is brown amphibole, which is found dispersed throughout the matrix of the gabbros and basalts, as well as filling veinlets or lining vesicles in the basalts.

The brown amphibole filling certain veinlets several millimeters thick has been dated as Late Jurassic (158 \pm $4.5 \mathrm{Ma}$ ) by ${ }^{40} \mathrm{Ar} /{ }^{39} \mathrm{Ar}$ with laser probe (Puga et al. 1991 , 1995, 2002). This result is in agreement with the hypothesis that this amphibole originated during the process of ocean-floor metamorphism, which would be coeval with or slightly later than the BOA magmatism generated throughout the Jurassic (Puga et al. 1995, 2002).

In this work, we characterize geochemically and mineralogically the brown amphibole and other minerals filling veins in the BOA metabasalts in Cóbdar, by optical microscopy, electron-microprobe analysis (EMPA) and transmission electron microscopy with analytical electron microscopy (TEM-AEM). In addition, we infer the conditions of formation of these amphiboles by comparing them with amphiboles in metabasites from the current ocean floor and from ophiolitic associations, and with the different assemblages found in the host metabasalt.

\section{MethodS}

Polished and carbon-coated thin sections were imaged using back-scattered electrons and analyzed by electron microprobe (EMPA), using a Cameca SX-50 instrument at the University of Granada. The following standards were used: wollastonite ( $\mathrm{Si}$ and $\mathrm{Ca}$ ), synthetic $\mathrm{Al}_{2} \mathrm{O}_{3}(\mathrm{Al})$, orthoclase $(\mathrm{K})$, albite $(\mathrm{Na})$, synthetic $\mathrm{Fe}_{2} \mathrm{O}_{3}$ $(\mathrm{Fe})$, periclase $(\mathrm{Mg})$, and synthetic $\mathrm{MnTiO}_{3}(\mathrm{Mn}$ and Ti).

Selected samples were studied with a $200 \mathrm{kV}$ Philips CM-20 transmission electron microscope (TEM) at the University of Granada, fitted with a scanning transmission device and a solid-state detector for energy-dispersion analysis (EDX). Micro-analyses were carried out in STEM mode. Albite (Na), muscovite and annite (K), albite, spessartine and muscovite ( $\mathrm{Al})$, forsterite and annite $(\mathrm{Mg}$ and $\mathrm{Fe})$, spessartine $(\mathrm{Mn})$, and titanite $(\mathrm{Ca}$ and $\mathrm{Ti}$ ) were used as standards.

Calculation of amphibole formulae followed the method proposed by Schumacher (1997), and the no- 


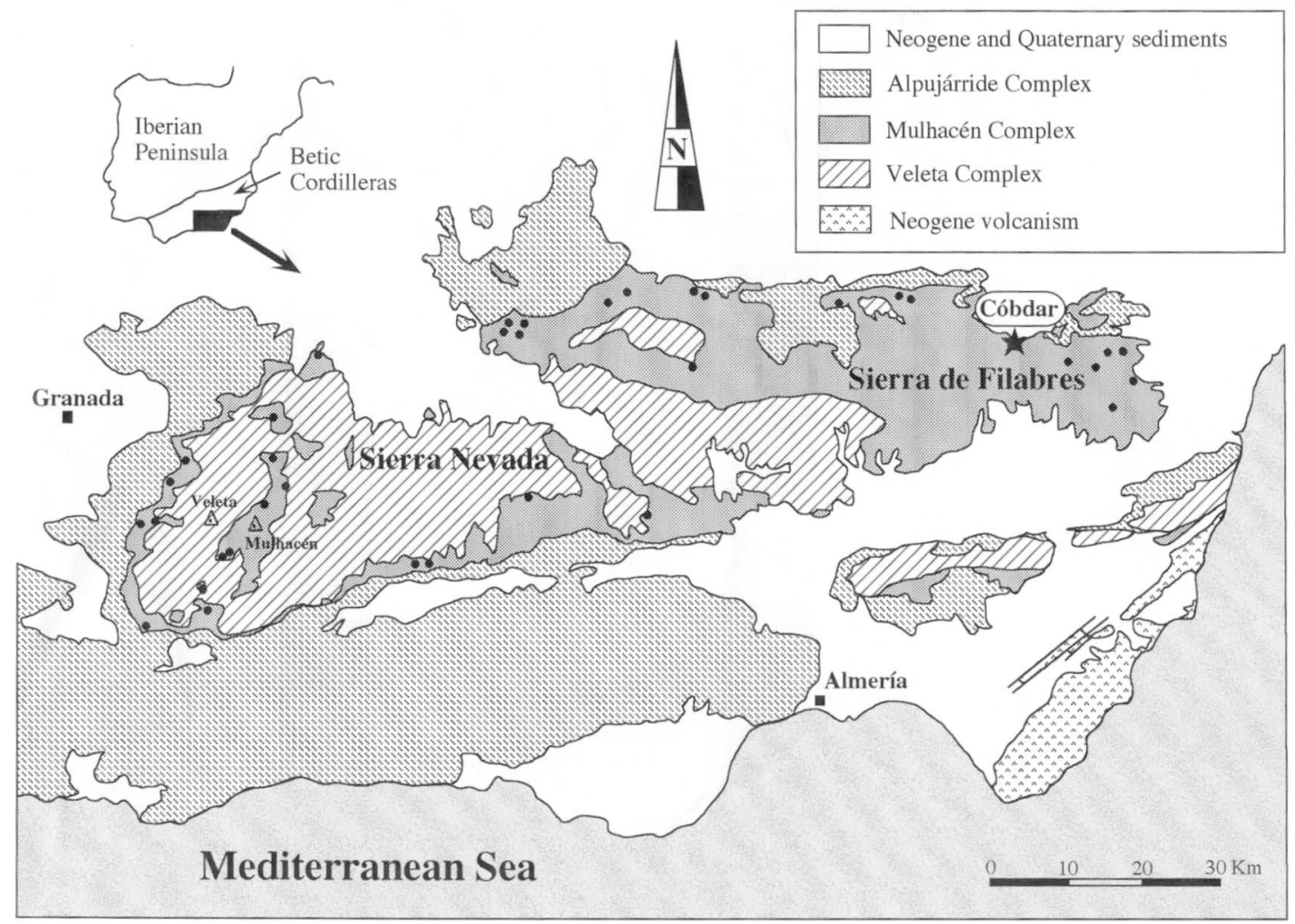

FIG. 1. Tectonic sketch-map showing the relationship among the deepest metamorphic complexes forming the central-eastern sector of the Betic Cordilleras and the location of the Cóbdar outcrop. Full dots on the Mulhacén Complex represent the location of the main outcrops of the Betic Ophiolitic Association exposed in Sierra Nevada and Sierra de Filabres. Limits between complexes according to Puga et al. (2002).

menclature of amphiboles conforms to the recommendations of Leake et al. (1997).

\section{Petrological and Geochemical Characteristics of the Host Basalt of the Amphibole Veins}

The basalt layer with the highest concentration of brown amphibole veins is located about $1 \mathrm{~km}$ north of Cóbdar village (Fig. 1). This layer is cut by scarce decimeter-thick diabasic dykes and presents well-preserved pillow structures at is upper part (Photo 3 in Puga et al. 1989a).

The Cóbdar pillow lavas are generally deformed, as is to be expected in an outcrop that, after oceanic metasomatism and metamorphism, underwent a subduction process, to a depth of about $40 \mathrm{~km}$, developing blueschists to eclogite facies and a second metamorphic event, attaining albite-epidote amphibolite facies (Puga et al. 1989a, 2000). Nevertheless, the pillow structures may easily be distinguished, in Cóbdar and in other outcrops of the same ophiolite suite, despite their defor- mation (see photos in Puga et al. 1989a, 1995), although Gómez-Pugnaire et al. (2000) have interpreted them as spheroidal blocks resulting from jointing by weathering of subvolcanic material.

The Cóbdar pillow lavas preserve vitreous or hypocrystalline rims transformed into very fine-grained metamorphic minerals, and contain a variolitic texture in their core (Puga et al. 1989a). The basalts also preserve their igneous textures, which tend to be very finegrained, vesicular and pilotaxitic (Figs. 2a-c, 3a), although most of them are transformed to amphibolites. The crystallization sequence of the phenocrysts in these basalts is typical of tholeiitic series: olivine, calcic plagioclase and clinopyroxene. This latter mineral is more common in the rock matrix, where it occupies the interstices between the plagioclase microlites, along with opaque phases (Figs. 2a-c, 3a). In this basalt horizon, all the igneous minerals are transformed into secondary metamorphic minerals (see Table 1 for representative chemical compositions). 
Both the microlites and the calcic plagioclase phenocrysts are transformed into clinozoisite with or without albite relics (anal. 1, Table 1). Olivine has been replaced by green amphibole of magnesiohornblende (anal. 2, Table 2) and actinolite compositions. The

TABLE 1. REPRESENTATIVE MINERALS IN METABASALT HOSTING AMPHIBOLE VEINS, COBDAR SUITE

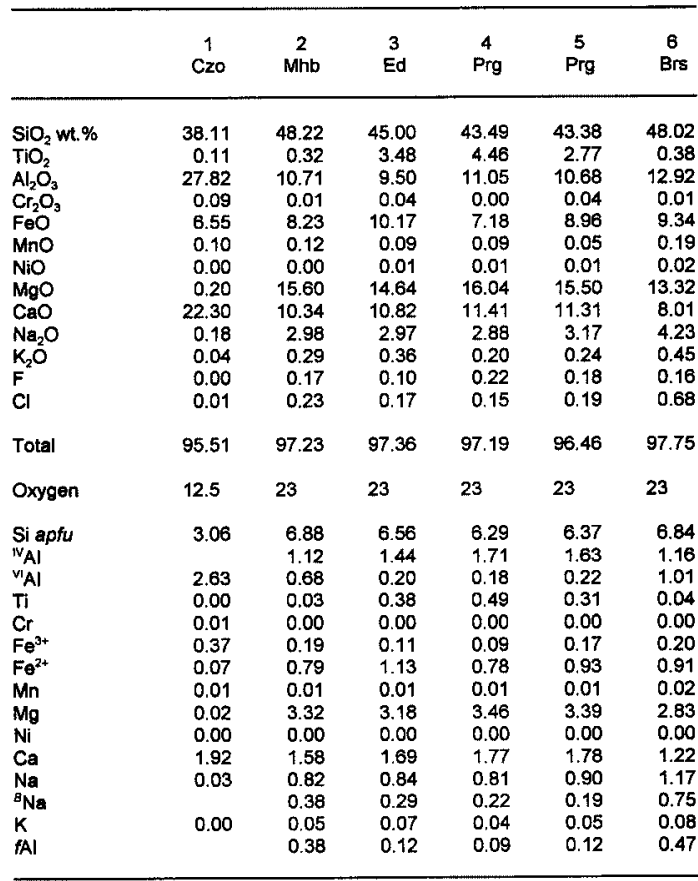

Columns 1 and 2: clinozoisite (Czo) and magnesiohomblende (Mhb) replacing igneous $\mathrm{PI}$ and $\mathrm{Ol}$. Columns 3 and 4: titanian edenite $(\mathrm{Ed})$ and titanian pargasite $(\mathrm{Prg})$ in the matrix and filling veins. Column 5: brown titanian pargasite ( $\mathrm{Prg}$ ) lining the walls of the vesicles. Column 6: pale green barroisite (Brs) filling the intemal zone of vesicles. apfu: atoms per formula unit, fAl: ${ }^{\mathrm{V}} \mathrm{Al} / \mathrm{Al}$. clinopyroxene in the matrix has mostly been replaced by brown amphibole with a titanian edenite or titanian pargasite composition (anal. 3 and 4, Table 1). Scarce phenocrysts have an augite composition in the core with gradual transitions toward sodian augite in the rim (Puga et al. 2000). The metabasalt vesicles are filled by a brown amphibole similar to that in the basalt matrix, titanian pargasite in composition at point C (Fig. 2a, anal. 5 in Table 1). This brown amphibole is overgrown by green amphibole in the inner part of the vesicles, with a barroisite composition at point $\mathrm{C} 1$ (Fig. 2a and anal. 6 in Table 1).

Despite the chemical changes produced by polyphase metamorphism that affected these basalts, their geochemical characteristics are typical of a MORB-type basalt enriched in light rare-earth elements (LREE), similar to others constituting the BOA (Bodinier et al. 1987, Morten et al. 1987, Puga et al. 1989a, b, 1995, 2002). The rocks preserving mineral relics of oceanfloor metamorphism have very low $\mathrm{Cu} / \mathrm{Zn}$ values, which indicate high-temperature conditions during this process, according to the observations of Gillis \& Thompson (1993) made on metabasalts from the Mid-Atlantic Ridge.

The Cóbdar metabasic rocks, like the BOA in general, originated during a period of Jurassic sea-floor spreading that followed a stage of Permian and Triassic rifting, both documented by isotope geochronology (Hebeda et al. 1980, Portugal Ferrera et al. 1988, Nieto 1996, Nieto et al. 1997, Puga et al. 1991, 1995, 2002).

\section{Description of the Amphibole Veins}

The pre-Alpine brown amphibole in these veins is found in plutonic, subvolcanic and volcanic rocks in numerous outcrops of the BOA. However, it normally appears as relics more or less transformed into green amphibole and associated minerals during the Alpine

FIG. 2. a. Vesicular metabasalt with intersertal groundmass, containing some microphenocrysts of plagioclase (Pl) replaced by metamorphic albite and clinozoisite (Czo). Brown amphibole replaces the pre-existing interstitial clinopyroxene or glass preexisting among the plagioclase microlites, and partly lines the external zone of vesicles and veins (br Amp). This type of amphibole, titanian pargasite in composition at point $\mathrm{C}$, is overgrown by green amphibole (gr Amp), barroisite at point $\mathrm{C}$, which forms an inner corona in the vesicles and the innermost parts of some veins. Red arrow marks the evolutionary trend among the types of amphibole filling the vesicles. The abbreviations of minerals suggested by Kretz (1983), complemented by Spear (1993), have been used in figures and tables. b. Localized conversion of a metabasalt to amphibolite following microfissures. Brown titanian pargasite (Ti Prg) develops preferentially from clinopyroxene and opaque phase, interstitial in the framework formed by plagioclase microlites, and along fissures. Igneous plagioclase is replaced by albite and clinozoisite. c. Interface between basalt converted to amphibolite and a vein, several millimeters thick, mainly formed by a framework of brown amphibole with interstitial plagioclase. Brown amphibole in the veins has the same composition as in the groundmass of the host rock and developed in an extensional regime, as indicated by the preferential elongation of many crystals perpendicular to the vein wall. d. Enlargement of an internal zone of the previous vein showing hypidiomorphic brown amphibole and interstitial sodic-calcic plagioclase containing numerous clinozoisite micro-inclusions, and forming the first paragenesis filling these veins. A thin irregular border of pale green amphibole is present along the contacts between brown amphibole and plagioclase (lower part of the photo). Some crystals of brown amphibole are partly transformed into green amphibole containing rutile (Rt) micro-inclusions, which are in contact with albite containing clinozoisite micro-inclusions (central and upper part of the photo) and surround occasional crystals of tourmaline (Tour). 

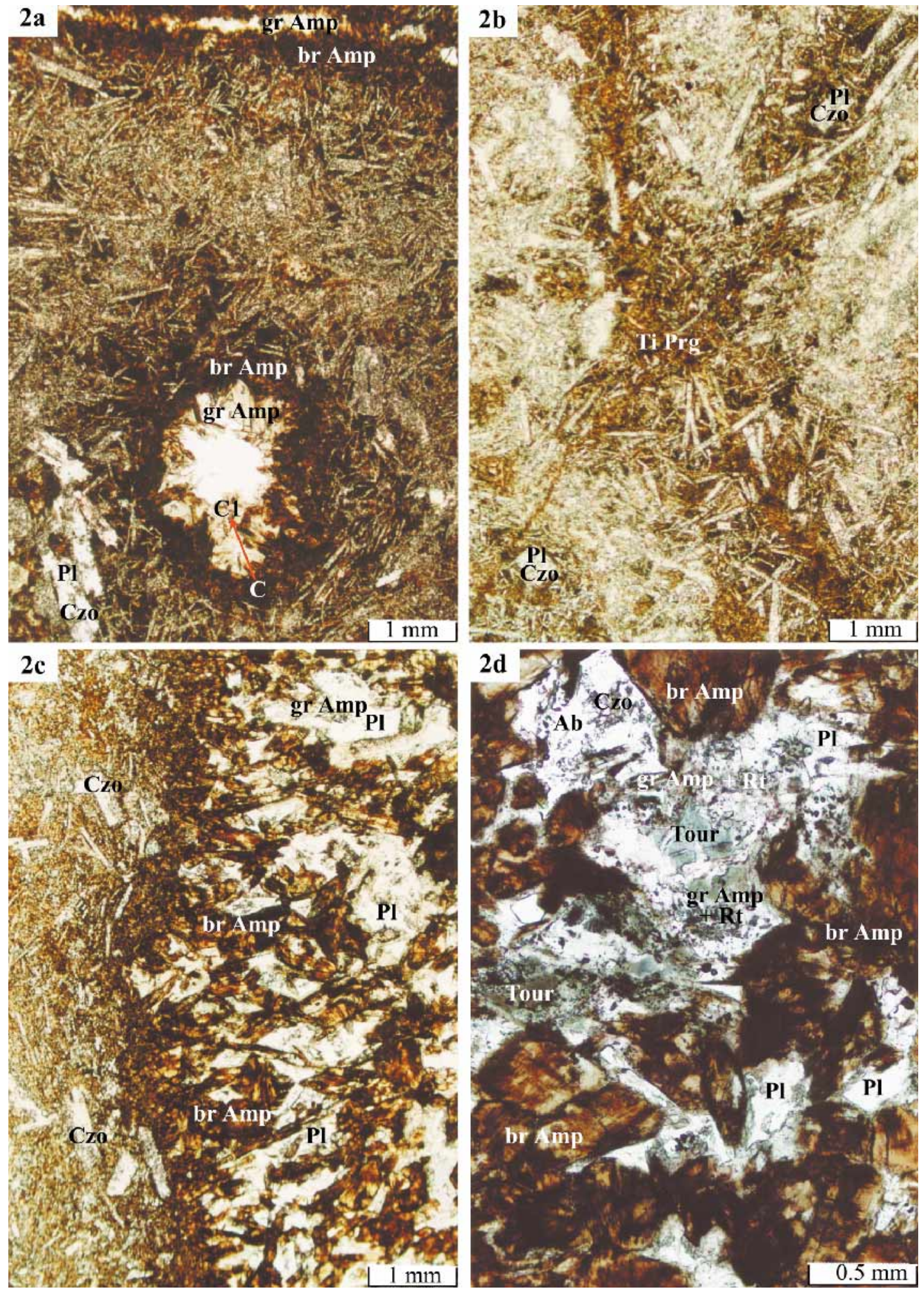
metamorphism. The preservation of brown amphibolefilled veins has only been documented in the Cóbdar metabasalts, among the different BOA outcrops studied
(Bodinier et al. 1987, Morten et al. 1987, Puga et al. 1989a, b, 1995). The orogenic metamorphism causing the destabilization of this brown amphibole thus must

TABLE 2. REPRESENTATIVE COMPOSITION OF MINERALS IN AMPHIBOLE VEINS, CÓBDAR SUITE

\begin{tabular}{|c|c|c|c|c|c|c|c|c|c|c|c|c|c|}
\hline & $\begin{array}{c}1 \\
A b\end{array}$ & $\begin{array}{l}2 \\
\mathbf{P l}\end{array}$ & $\stackrel{3}{\text { Czo }}$ & $\begin{array}{c}4 \\
\text { Tur }\end{array}$ & $\begin{array}{c}5 \\
\text { Krs }\end{array}$ & $\begin{array}{c}6 \\
\text { Brs }\end{array}$ & $\begin{array}{c}7 \\
\text { Mkt }\end{array}$ & $\begin{array}{l}8 \\
T r\end{array}$ & $\begin{array}{c}9 \\
\text { Prg }\end{array}$ & $\begin{array}{c}10 \\
\text { Mtm }\end{array}$ & $\begin{array}{l}11 \\
\text { Brs }\end{array}$ & $\frac{12}{\mathrm{Tr}}$ & $\begin{array}{c}13 \\
\text { Mhb }\end{array}$ \\
\hline $\begin{array}{l}\mathrm{SiO}_{2} \mathrm{wt} . \% \\
\mathrm{TiO}_{2} \\
\mathrm{Al}_{2} \mathrm{O}_{3} \\
\mathrm{Cr}_{2} \mathrm{O}_{3} \\
\mathrm{FeO} \mathrm{O} \\
\mathrm{MnO} \\
\mathrm{NiO} \\
\mathrm{MgO} \\
\mathrm{CaO} \\
\mathrm{Na}_{2} \mathrm{O} \\
\mathrm{K}_{2} \mathrm{O} \\
\mathrm{F} \\
\mathrm{Cl}\end{array}$ & $\begin{array}{r}67.29 \\
0.02 \\
20.59 \\
0.02 \\
0.11 \\
0.00 \\
0.00 \\
0.00 \\
0.93 \\
11.56 \\
0.03 \\
0.00 \\
0.00\end{array}$ & $\begin{array}{r}65.50 \\
0.00 \\
21.47 \\
0.01 \\
0.14 \\
0.00 \\
0.01 \\
0.00 \\
2.19 \\
10.71 \\
0.05 \\
0.00 \\
0.00\end{array}$ & $\begin{array}{r}37.41 \\
0.11 \\
27.51 \\
0.02 \\
6.93 \\
0.20 \\
0.01 \\
0.13 \\
22.98 \\
0.00 \\
0.00 \\
0.04 \\
0.00\end{array}$ & $\begin{array}{c}37.054 \\
0.06 \\
29.181 \\
0.01 \\
8.84 \\
0.02 \\
0.01 \\
8.291 \\
1.36 \\
2.22 \\
0.02 \\
0.08 \\
0.00\end{array}$ & $\begin{array}{r}42.735 \\
4.65 \\
11.01 \\
0.03 \\
8.18 \\
0.07 \\
0.02 \\
15.18 \\
11.37 \\
3.14 \\
0.20 \\
0.23 \\
0.18\end{array}$ & $\begin{array}{r}51.81 \\
0.16 \\
9.15 \\
0.00 \\
6.25 \\
0.20 \\
0.02 \\
16.88 \\
8.64 \\
3.31 \\
0.24 \\
0.14 \\
0.24\end{array}$ & $\begin{array}{r}46.54 \\
0.48 \\
13.84 \\
0.01 \\
8.29 \\
0.16 \\
0.02 \\
13.62 \\
8.19 \\
4.26 \\
0.46 \\
0.15 \\
0.55\end{array}$ & $\begin{array}{r}55.81 \\
0.05 \\
2.85 \\
0.00 \\
5.20 \\
0.17 \\
0.04 \\
20.13 \\
10.68 \\
1.42 \\
0.10 \\
0.18 \\
0.09\end{array}$ & $\begin{array}{r}43.43 \\
4.54 \\
10.57 \\
0.03 \\
7.11 \\
0.05 \\
0.02 \\
15.86 \\
11.35 \\
2.84 \\
0.20 \\
0.21 \\
0.16\end{array}$ & $\begin{array}{r}44.84 \\
0.32 \\
15.10 \\
0.02 \\
8.43 \\
0.16 \\
0.04 \\
13.42 \\
8.77 \\
4.08 \\
0.69 \\
0.26 \\
0.77\end{array}$ & $\begin{array}{r}48.82 \\
0.24 \\
11.44 \\
0.01 \\
7.84 \\
0.16 \\
0.05 \\
14.97 \\
8.67 \\
3.56 \\
0.40 \\
0.17 \\
0.46\end{array}$ & $\begin{array}{r}54.37 \\
0.11 \\
4.69 \\
0.00 \\
5.72 \\
0.16 \\
0.03 \\
19.12 \\
10.35 \\
1.80 \\
0.15 \\
0.20 \\
0.09\end{array}$ & $\begin{array}{r}47.54 \\
0.29 \\
9.63 \\
0.00 \\
7.87 \\
0.10 \\
0.05 \\
15.73 \\
10.92 \\
2.24 \\
0.33 \\
0.22 \\
0.37\end{array}$ \\
\hline Total & 100.541 & 100.08 & 95.35 & 87.129 & $96.98 \mathrm{~g}$ & 97.02 & 96.55 & 96.71 & 96.38 & 96.89 & 96.78 & 96.79 & 95.28 \\
\hline $\begin{array}{l}\text { Oxygen } \\
\text { Cations }\end{array}$ & 8 & 8 & 12.5 & 19 & 23 & 23 & 23 & 23 & 23 & 23 & 23 & 23 & 23 \\
\hline $\begin{array}{l}\text { Si apfu } \\
{ }^{{ }^{v}} \mathrm{Al}\end{array}$ & $\begin{array}{l}2.936 \\
1.059\end{array}$ & $\begin{array}{l}2.882 \\
1.113\end{array}$ & 3.030 & 6.027 & $\begin{array}{l}6.252 \\
1.748\end{array}$ & $\begin{array}{l}7.250 \\
0.750\end{array}$ & 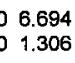 & $\begin{array}{ll}4 & 7.780 \\
6 & 0.220\end{array}$ & $\begin{array}{ll}0 & 6.343 \\
0 & 1.657\end{array}$ & $\begin{array}{ll}3 & 6.478 \\
7 & 1.522\end{array}$ & $\begin{array}{ll}8 & 6.955 \\
2 & 1.045\end{array}$ & $\begin{array}{ll}5 & 7.596 \\
5 & 0.404\end{array}$ & $\begin{array}{l}6.935 \\
1.065\end{array}$ \\
\hline $\begin{array}{l}\mathrm{Cl}^{\mathrm{Al}} \\
\mathrm{Ti} \\
\mathrm{Cr} \\
\mathrm{Fe}^{3+} \\
\mathrm{Fe}^{2+} \\
\mathrm{Mn} \\
\mathrm{Mg} \\
\mathrm{Ni} \\
\mathrm{Ca} \\
\mathrm{Na} \\
{ }^{8} \mathrm{Na} \\
\mathrm{K} \\
\mathrm{fAl}\end{array}$ & $\begin{array}{l}0.001 \\
0.001 \\
0.004 \\
0.000 \\
0.000 \\
0.000 \\
0.043 \\
0.978 \\
0.002\end{array}$ & $\begin{array}{ll}1 & 0.000 \\
1 & 0.000 \\
4 & 0.005 \\
0 & 0.000 \\
0 & 0.000 \\
0 & 0.000 \\
3 & 0.103 \\
8 & 0.913 \\
2 & 0.003\end{array}$ & 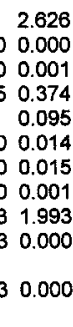 & $\begin{array}{ll}3 & 5.594 \\
0 & 0.007 \\
1 & 0.001 \\
4 & \\
5 & 1.203 \\
4 & 0.002 \\
5 & 2.009 \\
1 & 0.001 \\
3 & 0.237 \\
0 & 0.699 \\
0 & 0.004\end{array}$ & $\begin{array}{l}0.150 \\
0.511 \\
0.003 \\
0.031 \\
0.970 \\
0.008 \\
3.311 \\
0.000 \\
1.782 \\
0.891 \\
0.218 \\
0.037 \\
0.08\end{array}$ & $\begin{array}{l}0.760 \\
0.017 \\
0.000 \\
0.259 \\
0.472 \\
0.024 \\
3.522 \\
0.001 \\
1.291 \\
0.898 \\
0.652 \\
0.043 \\
0.50\end{array}$ & $\begin{array}{ll}0 & 1.040 \\
7 & 0.052 \\
0 & 0.001 \\
9 & 0.205 \\
2 & 0.791 \\
4 & 0.019 \\
2 & 2.920 \\
1 & 0.001 \\
1 & 1.262 \\
8 & 1.189 \\
2 & 0.709 \\
3 & 0.084 \\
& 0.443\end{array}$ & $\begin{array}{ll}0 & 0.248 \\
2 & 0.005 \\
1 & 0.000 \\
5 & 0.187 \\
1 & 0.420 \\
9 & 0.020 \\
0 & 4.182 \\
1 & 0.004 \\
2 & 1.596 \\
9 & 0.383 \\
9 & 0.338 \\
4 & 0.018 \\
3 & 0.531\end{array}$ & $\begin{array}{ll}8 & 0.161 \\
5 & 0.499 \\
0 & 0.004 \\
7 & 0.045 \\
0 & 0.823 \\
0 & 0.007 \\
2 & 3.452 \\
4 & 0.000 \\
6 & 1.776 \\
3 & 0.805 \\
8 & 0.224 \\
8 & 0.038 \\
1 & 0.089\end{array}$ & $\begin{array}{ll}1 & 1.050 \\
9 & 0.035 \\
4 & 0.002 \\
5 & 0.223 \\
3 & 0.795 \\
7 & 0.020 \\
2 & 2.891 \\
0 & 0.002 \\
6 & 1.358 \\
5 & 1.142 \\
4 & 0.622 \\
8 & 0.127 \\
9 & 0.408\end{array}$ & $\begin{array}{ll}0 & 0.877 \\
5 & 0.026 \\
2 & 0.001 \\
3 & 0.237 \\
5 & 0.696 \\
0 & 0.019 \\
1 & 3.180 \\
2 & 0.003 \\
8 & 1.324 \\
2 & 0.982 \\
2 & 0.635 \\
7 & 0.073 \\
8 & 0.635\end{array}$ & $\begin{array}{ll}7 & 0.369 \\
6 & 0.012 \\
1 & 0.000 \\
7 & 0.238 \\
6 & 0.430 \\
9 & 0.019 \\
0 & 3.981 \\
3 & 0.001 \\
4 & 1.550 \\
2 & 0.488 \\
5 & 0.398 \\
3 & 0.027 \\
5 & 0.477\end{array}$ & $\begin{array}{l}0.590 \\
0.032 \\
0.000 \\
0.166 \\
0.794 \\
0.012 \\
3.420 \\
0.003 \\
1.707 \\
0.634 \\
0.273 \\
70.061 \\
0.357\end{array}$ \\
\hline
\end{tabular}

Symbols used: Ab: albite, Pl: plagioclase, Czo: clinozoisite, Tur: tourmaline, Krs: kaersutite, Brs: barroisite, Mkt: magnesiokatophorite, Tr: tremolite, Prg: pargasite, Mtm: magnesiotaramite, Mhb: magnesiohomblende. apfu: atoms per formula unit, $\mathrm{fAl}:{ }^{\mathrm{VI}} \mathrm{Al} / \mathrm{Al}$.

FIG. 3. a. Contact between a basalt converted to amphibolite and a millimetric vein mainly containing pale green amphibole in a calcite matrix $(\mathrm{Cal})$. Both minerals show a preferential elongation similar to that exhibited by the brown amphibole filling other parts of the same vein (Fig. 2c). The brown amphibole has been better preserved in the groundmass of the metabasalt than in the vein, in which only scarce relics form cores, overgrown by green amphibole. The limit between the metabasalt and the vein is marked by a black border of rutile micro-inclusions in green amphibole, both replacing the pre-existing brown amphibole. Corroded micro-phenocrysts of olivine in the metabasalt have also been replaced by green amphibole, whereas the plagioclase microlites are mainly replaced by clinozoisite. b. Several relics of brown amphibole (kaersutite at point A), preserved in the previous vein, are partly transformed into a thick corona of green amphibole (barroisite at A1) crowded by microscopic grains of rutile, and overgrown by a rim of clean green amphibole. The composition of this rim corresponds to sodic-calcic amphibole (katophorite at A2), or to a calcic type (tremolite at A3). Red arrows mark the evolutionary trends found in this overgrowth crystal from the brown core to the different microdomains forming the corona. c. Hypidiomorphic relic of brown amphibole (titanian pargasite at point B), less transformed than in Figure $3 \mathrm{~b}$ in the green amphibole + rutile association (magnesiotaramite at B1), which develops following micro-fissures from the periphery toward the core of the crystal. Both types of amphibole are overgrown by a rim of green amphibole of varied composition, as shown by points B2, with barroisite composition, or B3 and B4, with tremolite and magnesiohornblende composition, respectively. d. Same thin section as in Figure 3c, under crossed nicols, showing a similar optical orientation of the green amphibole rims, which overgrew the fractured and partly transformed crystals of brown amphibole into rutile plus green amphibole, and the calcite matrix surrounding the green amphiboles. 

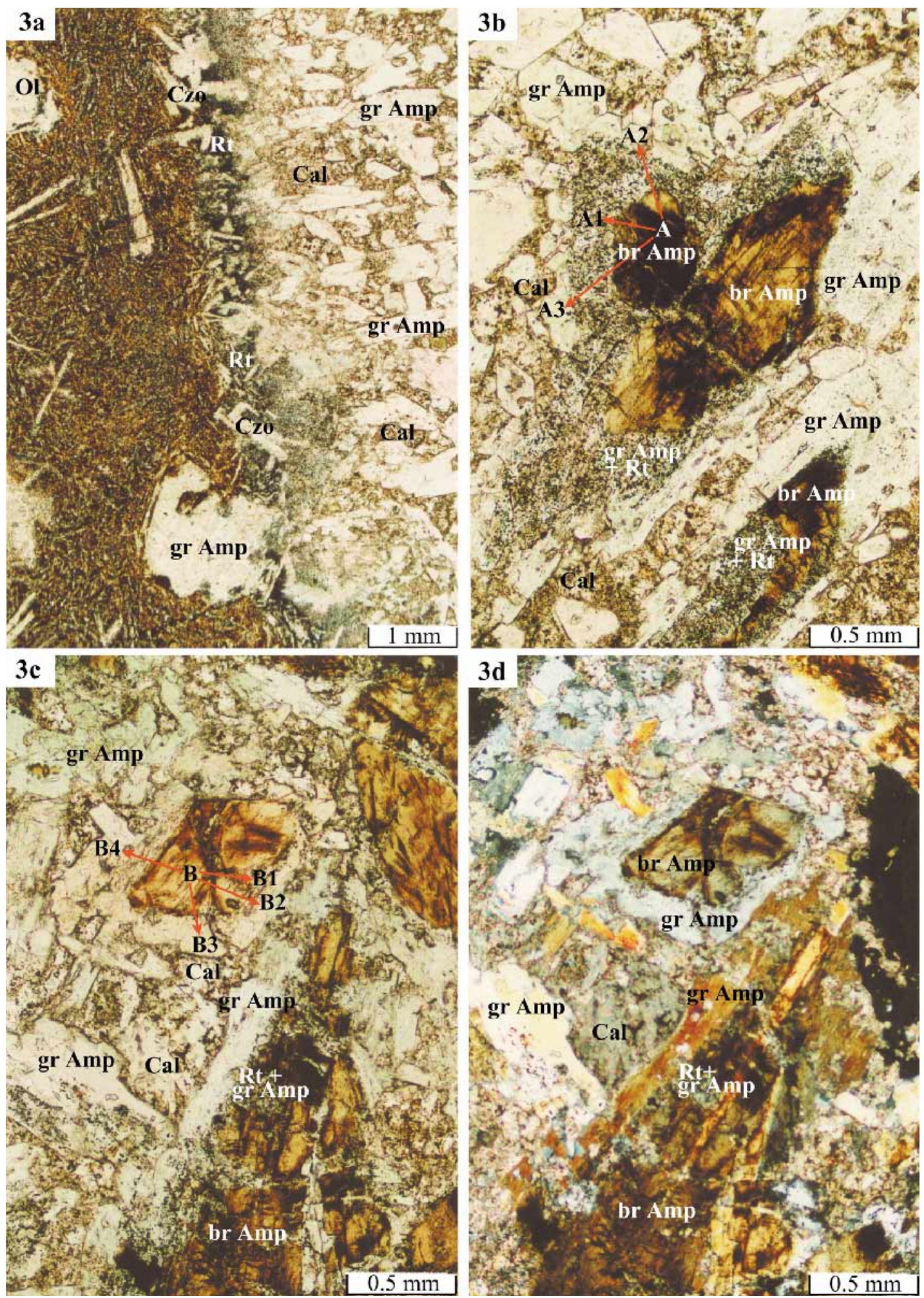

3

3d
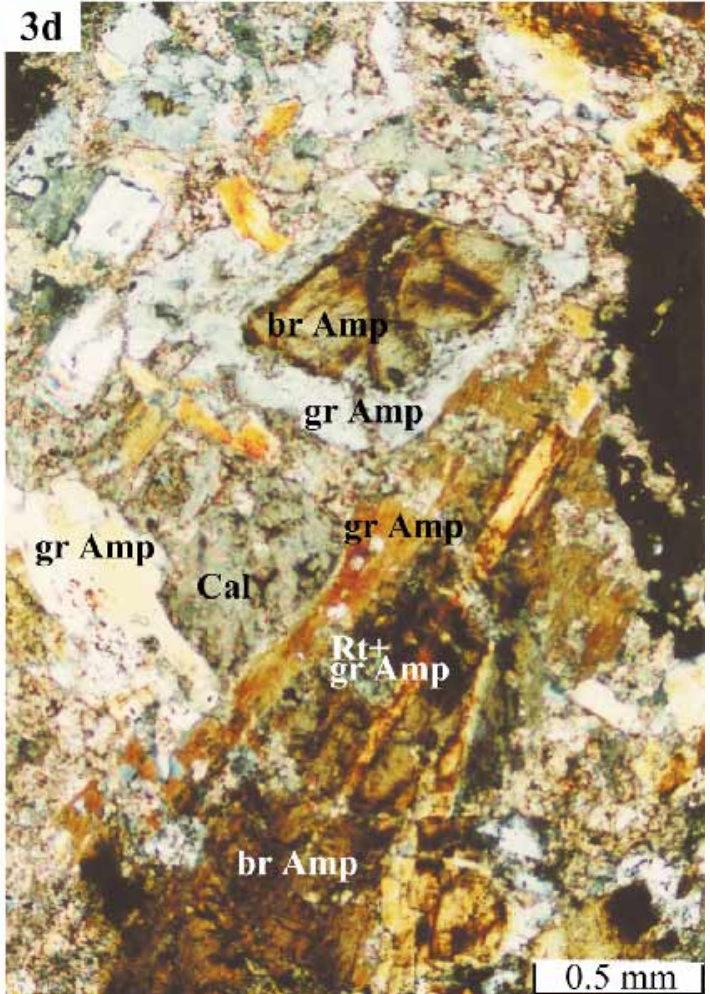
have been less pervasive in this outcrop. This inference would also account for the local preservation in this outcrop of both the igneous paragenesis and the microfossils in the calc-schists of the overlying sedimentary sequence (Puga et al. 1989a, 1999a, Tendero et al. 1993).

In the first stages of their evolution, the veinlets occur as concentrations of brown amphibole $<1 \mathrm{~mm}$ thick replacing the clinopyroxene in the basalt matrix along microfissures (Fig. 2b). These microfissures have been preferential pathways for the circulation of fluids necessary for the formation of the amphibole from the anhydrous minerals of the basalt. In a subsequent stage, the brown amphibole crystallized to form a monomineralic band lining the vesicle walls and veinlets, within which the brown amphibole is usually overgrown by green amphibole (Fig. 2a). In a more advanced stage, the veins can reach several millimeters in thickness, with the brown amphibole being accompanied by other minerals such as plagioclase (with clinozoisite inclusions), green amphibole (with locally abundant inclusions of rutile), calcite and scarce tourmaline crystals.

In the veins where brown amphibole predominates (e.g., Figs. 2a-c), its composition generally varies between kaersutite and titanian pargasite. It forms a network with sodic plagioclase as the predominant phase in the interstices (anal. 1 and 2, Table 2), commonly containing inclusions of clinozoisite (anal. 3, Table 2). This association suggests that the brown amphibole coexisted with a more calcic plagioclase than the one currently preserved, and that most of its calcium was consumed to form clinozoisite. Under greater magnification, a portion of the same vein (Fig. 2d) shows the incipient development of sodic-calcic green amphibole at the contacts between the brown amphibole and the plagioclase, as well as the partial transformation of some brown amphibole crystals into a green amphibole containing abundant exsolution-induced inclusions of rutile. The green amphibole also surrounds tourmaline crystals (anal. 4, Table 2), as can be seen in Figure 2d, and interstices contain rare crystals of calcite.

In other veins, or in other parts of the same vein, and even within the same thin section, the brown amphibole has the same composition as in the afore-mentioned veins (anal. 5 and 9, Table 2), but it is preserved only as relics. These relics are partially transformed, or surrounded, by abundant green amphibole, with or without exsolved rutile, with interspersed calcite crystals (Figs. $3 \mathrm{a}-\mathrm{d}$ ). The calcic (anal. 8 and 12, Table 2) or sodiccalcic (anal. 6, 7, 10, 11 and 13, Table 2) composition of the green amphibole depends on whether or not it is in contact with the calcite in the matrix, indicating that these two minerals form part of the same assemblage. Where calcite is abundant between the amphibole grains, plagioclase is minor or non-existent (Figs. 3ad), although they can locally coexist (Fig. 2d).

The textural relationships described above among the different minerals comprising these veins, their ge- netic conditions, and the relative abundances of the brown and green amphiboles in different veins or parts of the same vein, allow these minerals to be grouped into two generations of assemblages. The first assemblage comprises the brown amphibole, an interstitial plagioclase (originally more calcic than the current one) and tourmaline. The second assemblage consists of the different types of green amphibole present in these veins, rutile, sodic plagioclase and its clinozoisite inclusions, and the calcite in the matrix.

\section{Chemical Evolution and Environment of Formation of the Amphiboles in the Veins}

In Figures 4 to 8, we compare the composition of the brown and green amphiboles in these veins with the amphiboles from certain representative outcrops of basic rocks affected by ocean-floor metamorphism from modern oceanic ridges and some Jurassic Apennine ophiolites. These latter outcrops were chosen for comparison (among other ophiolites deriving from the Western Tethyan Jurassic ocean floor) because the ocean-floor metamorphic assemblages have been well preserved in them despite the superimposed Alpine metamorphism.

Figure 4 shows the clear separation of the amphiboles studied into two groups with different Ti and ${ }^{\mathrm{IV}} \mathrm{Al}$ contents. The brown amphiboles are indicative of genesis at a higher temperature than the green amphiboles, which overgrow them (Raase 1974, Robinson et al. 1982). Both groups plot within the field of Ti versus ${ }^{\mathrm{IV}} \mathrm{Al}$ composition of the amphiboles from present-day oceanic ridges and from the Apennine ophiolites. Nevertheless, only the brown amphibole shows a variation trend of Ti versus ${ }^{\mathrm{IV}} \mathrm{Al}$ similar to that of the ocean-floor amphiboles. We interpret the lower $\mathrm{Ti}:{ }^{\mathrm{IV}} \mathrm{Al}$ ratio in the green amphiboles than in the amphiboles from the other oceanic environments to indicate a lower geothermal gradient.

The trend of increasing temperature for the oceanfloor amphiboles is accompanied by a decrease in the water:rock ratio, as deduced by Vanko (1986) and Stakes \& Vanko (1986) for amphiboles of the Mathematician Ridge, also plotted in Figure 4. The brown amphiboles developed in the oceanic outcrops presented for comparison in Figure 4, acquired their high Ti and ${ }^{\mathrm{IV}} \mathrm{Al}$ values in postmagmatic conditions, at high temperatures and under the influence of igneous or oceanic fluids.

The high temperatures deduced for the brown amphiboles in the Cóbdar veins, based on their $\mathrm{TiO}_{2}$ contents, which ranges from 3 to $6 \mathrm{wt} . \%$, may be appropriate for the development of amphiboles in the ocean floor and ophiolites under the influence of igneous fluids (Tribuzio et al. 2000). On the other hand, their chlorine contents, between 0.2 and 0.8 wt.\% (Tables 1,2 ), suggest an influx of fluid derived from ocean water (Vanko 1986, Prichard \& Cann 1982, Mével 1988). 


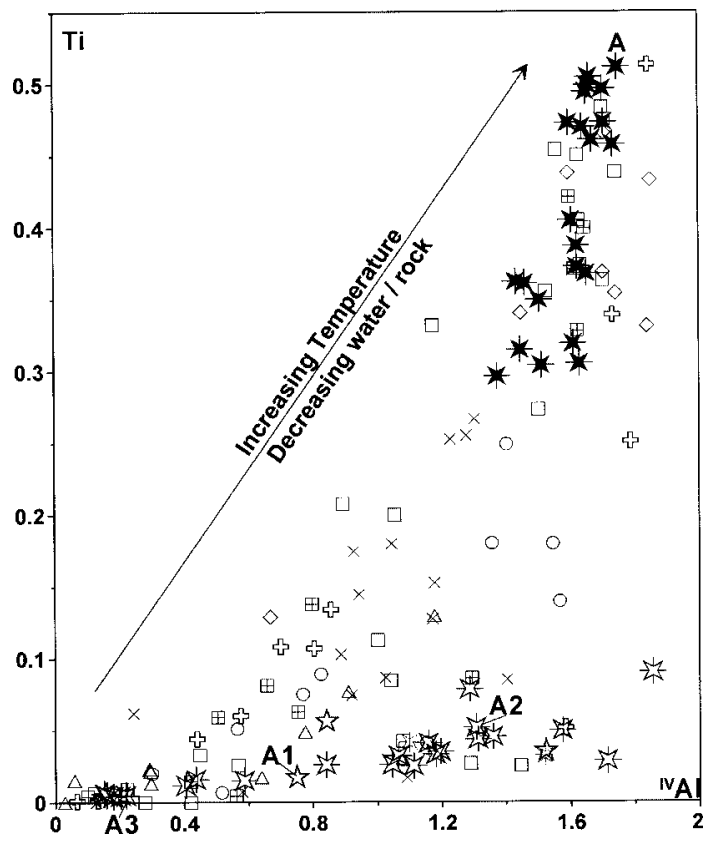

FIG. 4. Plot of Ti versus ${ }^{\mathrm{IV}} \mathrm{Al}($ apfu) in the different types of amphibole filling millimetric veins in Cóbdar ophiolitic metabasalts, compared with amphiboles of basic rocks affected by ocean-floor metamorphism, taken from various oceanic ridges and ophiolite outcrops. A, A1, A2 and A3 correspond to different textural positions in an overgrowth amphibole crystal (Fig. 3b). Meaning of the symbols for

Cóbdar amphiboles: *: brown amphiboles constituting the first generation of amphiboles in these veins; $\hat{x}$ : transformation rims of the previous amphibole type to pale brown or green amphibole with exsolved microscopic inclusions of rutile; $\frac{s}{4}$ : pale green amphibole rimming the previous types and forming idiomorphic neoblasts in the same veins. Provenance of the amphiboles used for comparison and meaning of their symbols: $\square$ : metagabbros from Gettysburg Bank in the Gorringe Ridge, eastern part of the MidAtlantic Ridge (MAR) (Prichard \& Cann 1982); $\Delta$ and ↔: metagabbros and metabasalts, respectively, from $23-24^{\circ} \mathrm{N}$ in the MAR (Gillis et al. 1993, Gillis \& Thompson 1993); $\boxplus$ : metagabbros from Hole 735B in the Southwest Indian Ridge (SWIR) (Stakes et al. 1991); ○: metagabbros from the Mathematician Ridge failed spreading center in the East Pacific Rise (EPR) (Vanko 1986); $\times$ : metabasalts from the Northern Apennine Ophiolites (Cortesogno \& Lucchetti 1984); $\diamond:$ metagabbros from the Northern Apennine Ophiolites (Tribuzio et al. 2000).

High $\mathrm{TiO}_{2}$ contents can also be found in igneous titanian pargasite preserved in oceanic metabasic rocks, but such amphibole has a level of $\mathrm{K}$ mostly ranging between 0.6 and 0.8 wt. $\% \mathrm{~K}_{2} \mathrm{O}$ (Mével 1988), whereas the amphiboles that originated from ocean-floor metamorphism along ridges (Mével 1988, Gillis \& Thompson 1993) or in ophiolites (Cortesogno \& Luchetti 1984), have 0.2 to $0.3 \mathrm{wt} . \% \mathrm{~K}_{2} \mathrm{O}$, which is similar to that found in the brown amphiboles from Cóbdar veins (Tables 1 to 3). Therefore, the low $\mathrm{K}_{2} \mathrm{O}$ contents, together with the high $\mathrm{Ti}$ and ${ }^{\mathrm{IV}} \mathrm{Al}$ values, and their chlorine content, indicate that the brown amphiboles filling veins and replacing clinopyroxene in the matrix of the Cóbdar metabasalts developed in conditions of ocean-floor metamorphism.

Figure 5 shows the different types of amphibole present in the veins and in their host metabasalts on the ${ }^{B} \mathrm{Na}$ versus Si plot of Leake et al. (1997). The most common type of brown amphibole is titanian pargasite, which, in some crystals, gradually changes to kaersutite toward the core. The green amphiboles show greater compositional variation, barroisite, katophorite and tremolite being the most common. The arrows in this figure, joining relics of brown amphibole (points A and C) and their overgrowth rim, formed by green amphibole (points $\mathrm{Al}, \mathrm{A} 2, \mathrm{~A} 3$ and $\mathrm{C} 1$ ), represent two main evolutionary trends common among the amphiboles filling veins and vesicles. One of these trends, marked by the arrows ending at points $\mathrm{Al}, \mathrm{A} 2$ or $\mathrm{C} 1$, corresponds to the development of sodic-calcic amphiboles (barroisite, katophorite and taramite). The other trend, corresponding to arrow A-A3, gives rise to calcic amphibole (tremolite and actinolite). Magnesiohornblende also developed as an intermediate step along the evolutionary trends between the pre-existing brown amphiboles and the most common types of green amphibole mentioned above.

In Figure 5, we have also plotted, for comparison, the amphiboles from modern oceanic ridges and Apennine ophiolites shown on Figure 4. The field corresponding to the brown amphiboles mainly overlaps that of amphiboles generated by ocean-floor metamorphism, whereas the green amphiboles show clearly higher ${ }^{B} \mathrm{Na}: \mathrm{Si}$ ratios, consistent with a relative increase in their pressure of formation. Moreover, the temperature decrease that can be deduced from their drastically lower Ti contents, together with the textural relationship between the two types of amphibole (shown in Figs. 2 and 3), indicate that a process of orogenic metamorphism was responsible for both the destabilization of the brown amphiboles and the development of the green amphiboles deriving from the brown ones and their associated minerals. Some amphiboles from the Apennine Ophiolite metabasalts, with ${ }^{B} \mathrm{Na} / \mathrm{Si}$ values higher than in current oceanic metabasic rocks (Fig. 5), could also be the result of low-grade orogenic metamorphism, which, according to Cortesogno \& Lucchetti (1984), affected those ophiolites after the ocean-floor metamorphism.

In Figure 6, brown and green amphiboles plot in different fields according to their respective ${ }^{\mathrm{IV}} \mathrm{Al}$ and ${ }^{\mathrm{VI}} \mathrm{Al}$ values, without transitions between them. This figure allows us to deduce a pressure increase and a temperature decrease during growth of green amphiboles with respect to the brown, similarly to that indicated by their 
respective ${ }^{B} \mathrm{Na}$ and Ti values ( $c f$. Raase 1974, Brown 1977, Laird \& Albee 1981, Smith 1988, Cortesogno et al. 1994, Gaggero \& Cortesogno 1997). The compositional evolution of some relics of brown amphibole in their respective transformation-induced rims of green amphibole is represented by the arrows joining points $\mathrm{A}$ and $\mathrm{C}$ with points $\mathrm{Al}, \mathrm{A} 2, \mathrm{~A} 3$ and $\mathrm{C} 1$, respectively, and shown in Figures 3a and 2a.

The ocean-floor amphiboles used for comparison in this figure are located in the field corresponding to values of the ratio ${ }^{\mathrm{IV}} \mathrm{Al} /{ }^{\mathrm{VI}} \mathrm{Al}$ higher than the pargasitic substitution line, consistent to their genesis under a high geothermal gradient. The rare exceptions of amphiboles from metagabbros from the Gettysburg Bank and metabasalts from the MARK area, which plot to the right of this line, may have developed during an active intra-oceanic tectonic process affecting these outcrops (Prichard \& Cann 1982, Gillis \& Thompson 1993).

The plot of the brown amphiboles from Cóbdar veins and their host metabasalts in the field corresponding to amphiboles from ocean-floor and Apennine ophiolites (Fig. 6) suggests similar genetic conditions for all of them. Likewise, the plot of the Cóbdar green amphiboles, originated by overgrowth or destabilization of the brown ones, in the field delimited by the pargasitic and tschermakitic substitution lines indicates genetic conditions for this second generation of amphiboles under a lower geothermal gradient, similar to that deduced for metamorphism during the Alpine orogeny of the BOA (Puga et al. 1999a, 2000).

Finally, Figures $7 \mathrm{a}$ and $7 \mathrm{~b}$ show three examples of representative brown amphiboles transformed or over-

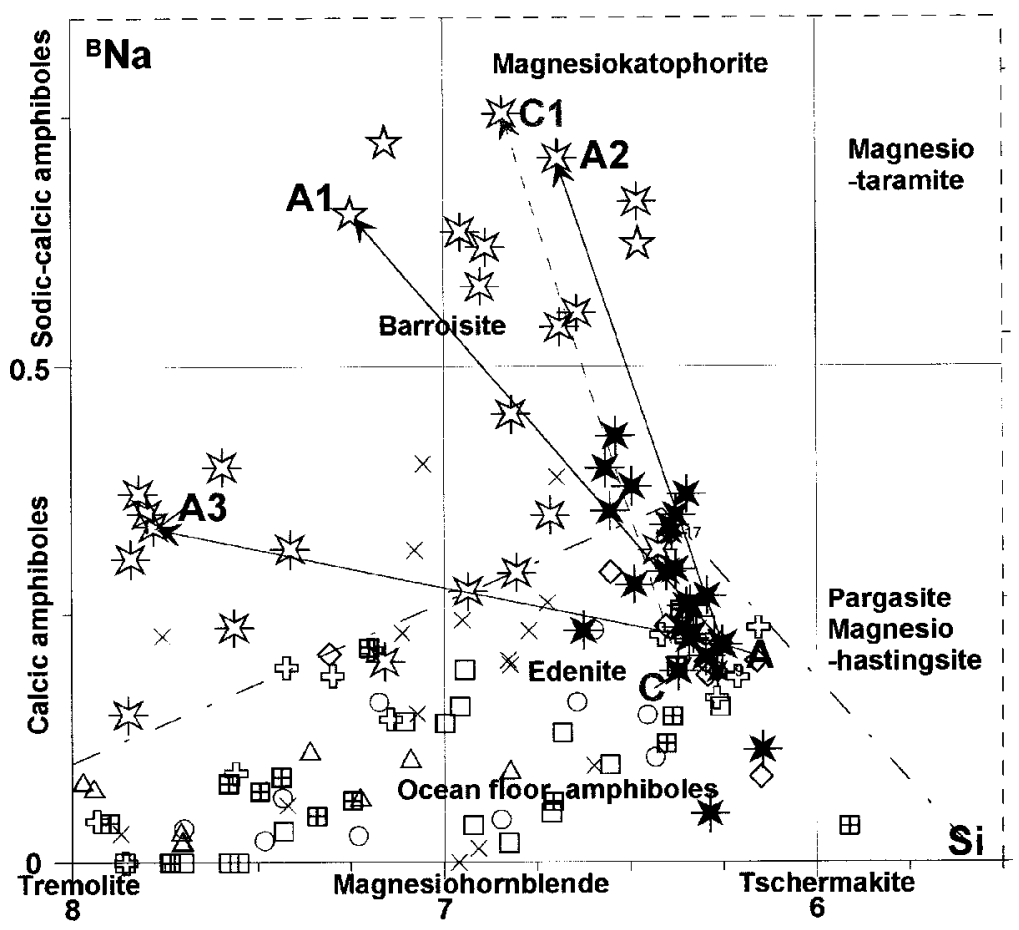

FIG. 5. Classification of amphiboles filling veins in Cóbdar metabasalts in the diagram of Leake et al. (1997). Some amphiboles formed by ocean-floor metamorphism, from different oceanic and ophiolitic basic rocks, have also been plotted for comparison, with the same symbols as in Figure 4. The continuous-line arrows linking the composition of the crystal core (A), with its transformation rim containing rutile micro-inclusions (A1) and with its overgrowth rims to pale-green amphibole (A2 and A3), represent the common evolutionary trends in the amphiboles filling the Cóbdar veins. The different microdomains joined by these arrows are shown in Figure $3 \mathrm{~b}$ with the same letters as in this figure. The dashed-line arrow represents a similar evolutionary trend found between the brown external corona lining vesicles, in the metabasalts hosting the veins $(\mathrm{C}$ in Figure 2a), and the inner green corona ( $\mathrm{C} 1$ in the same figure). The field corresponding to the ocean-floor amphiboles plotted in this figure is delimited by the dashed and dotted lines and the coordinate axes. 




FIG. 6. ${ }^{\mathrm{IV}} \mathrm{Al}$ versus ${ }^{\mathrm{VI}} \mathrm{Al}$ plot for amphiboles filling veins in Cóbdar metabasalts compared with amphiboles of basic rocks forming part of the present ocean floor and ophiolitic outcrops. Key for symbols as in Figure 4. The meaning of the arrows is the same as in Figure 5, and these correspond to the red arrows in Figure $3 \mathrm{~b}$. The pargasitic substitution line represents a lower limit for the ${ }^{\mathrm{IV}} \mathrm{Al}$ : ${ }^{\mathrm{VI}} \mathrm{Al}$ ratio corresponding to amphiboles generated in ocean-floor metamorphic conditions, with very rare exceptions.

grown by green amphiboles (Figs. 2a, 3b, c). In all of them, the ${ }^{B} \mathrm{Na}$ and ${ }^{\mathrm{VI}} \mathrm{Al}$ values increase in the second generation of amphiboles, whether the total $\mathrm{Na}$ and $\mathrm{Al}$ values increase or decrease. This fact confirms that the generalized increases in ${ }^{B} \mathrm{Na}$ and ${ }^{\mathrm{VI}} \mathrm{Al}$ in the green amphiboles, relative to the brown ones, were due to an increase in the pressure conditions during the formation of the latter, rather than an increase in $\mathrm{Na}$ or $\mathrm{Al}$ in the bulk-rock composition, or in the microsystems in the veins from which this second generation of amphiboles developed (Brown 1977, Smith 1988). In contrast, Figures $7 \mathrm{a}$ and $7 \mathrm{~b}$ suggest the conservation of the total $\mathrm{Na}$ and $\mathrm{Al}$ contents in both types of amphibole, despite the compositional diversification of the green amphibole.

\section{Chlorine Content in the Amphiboles}

Brown and green amphiboles present a similar range in chlorine contents, with maximum values of about 0.8 wt.\% (Fig. 8, Tables 1, 2). Nevertheless, the variation trends of $\mathrm{Na}, \mathrm{K}, \mathrm{Si}$ and $\mathrm{Fe}$ with respect to chlorine con-
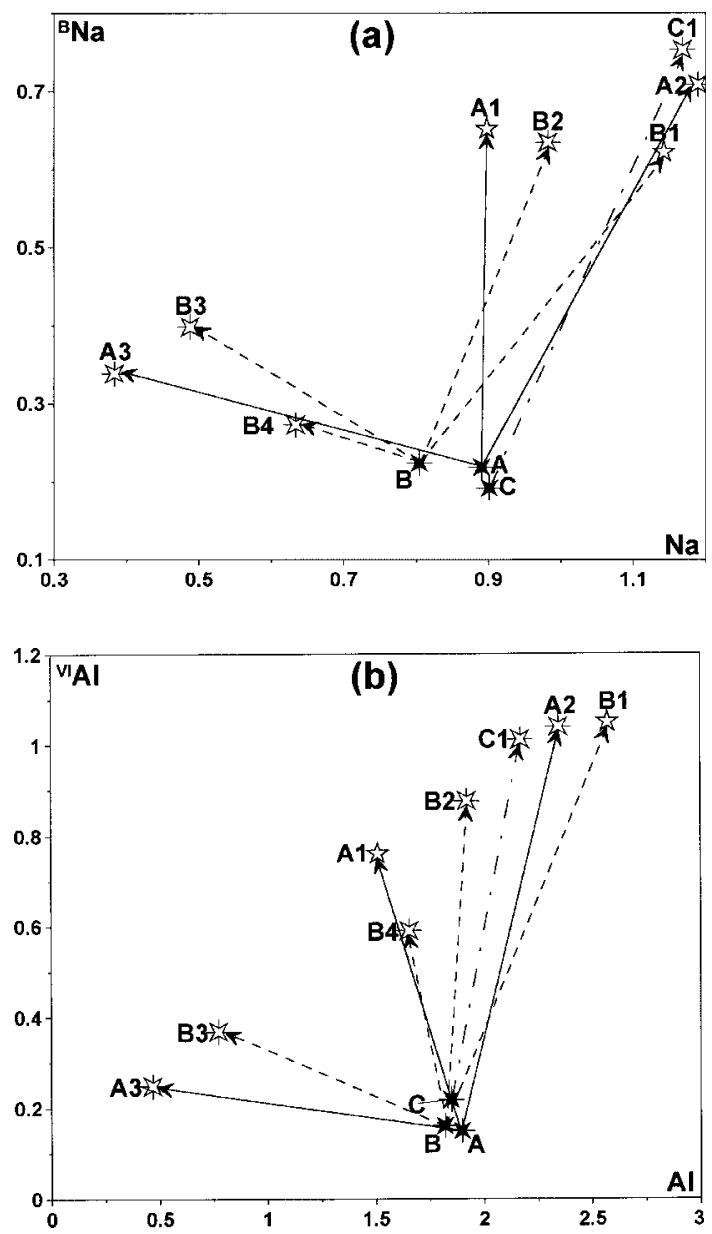

FIG. 7. Plot of ${ }^{B} \mathrm{Na}$ versus $\mathrm{Na}$ and ${ }^{\mathrm{VI}} \mathrm{Al}$ versus ${ }^{\mathrm{IV}} \mathrm{Al}$ (apfu), in (a) and (b), respectively, of some representative amphiboles filling veins in the Cóbdar metabasalts. The textural position of the A to A3 and B to B4 analyzed spots are shown in Figures $3 \mathrm{a}$ and $3 \mathrm{~b}$, and those corresponding to $\mathrm{C}$ and $\mathrm{C} 1$ are shown in Figure 2a. Arrows in this figure correspond to the red arrows joining similar letters in Figures $3 \mathrm{~b}$ and $3 \mathrm{c}$.

tent are different for the two generations of amphibole. The relationship of increasing chlorine content with increase in alkalis and $\mathrm{Fe}$ and decrease in $\mathrm{Si}$ is much clearer in the green amphiboles than in the brown ones, and could be indicative of the incorporation of $\mathrm{Cl}$ in the crystal structure of the second-generation amphiboles, according to Volfinger et al. (1984) and references herein. Moreover, a TEM/AEM study of both types of amphibole revealed the existence of numerous inclusions of $\mathrm{NaCl}$ present only in the brown amphiboles. The chlorine present in the brown amphiboles must have 
been incorporated from saline water acting on the metabasalt during the stage of oceanic metamorphism. The chlorine incorporated in the green amphiboles must be inherited from the brown amphiboles. The plot of the brown amphibole relic in Figure 8, composition A, and that of the green amphiboles, $\mathrm{Al}, \mathrm{A} 2$ and $\mathrm{A} 3$, deriving from this relic (as shown in Fig. 3b), suggest a probable partition of chlorine contained in the brown amphibole into the different types of amphiboles formed in the second assemblage. In fact, the percentage of chlorine present in the primary brown amphibole, crystal $\mathrm{A}$, increases in the secondary sodic-calcic green amphiboles, $\mathrm{Al}$ and $\mathrm{A} 2$, but decreases in the calcic one, of A3 type.

Brown amphibole contain also abundant inclusions of rutile and actinolite, which appear either as isolated crystals or as rutile-amphibole mixed inclusions (Fig. 9). These inclusions are irregularly distributed in the host crystal, which has a pargasitic composition. They are, moreover, aligned following crystallographic directions of the host amphibole. Hence they can be interpreted as having been exsolved from a primitive amphibole crystal that previously incorporated the components of these inclusions in its own structure, owing to its high temperature of formation. The exsolution of rutile and actinolite as micro-inclusions may have taken place either by cooling of the host amphiboles, during the retrograde evolution of the metabasalt, or most probably during their destabilization provoked by the subsequent orogenic metamorphism.

The compositions of these brown amphiboles determined by EMPA (Tables 1,2) must include the compo-
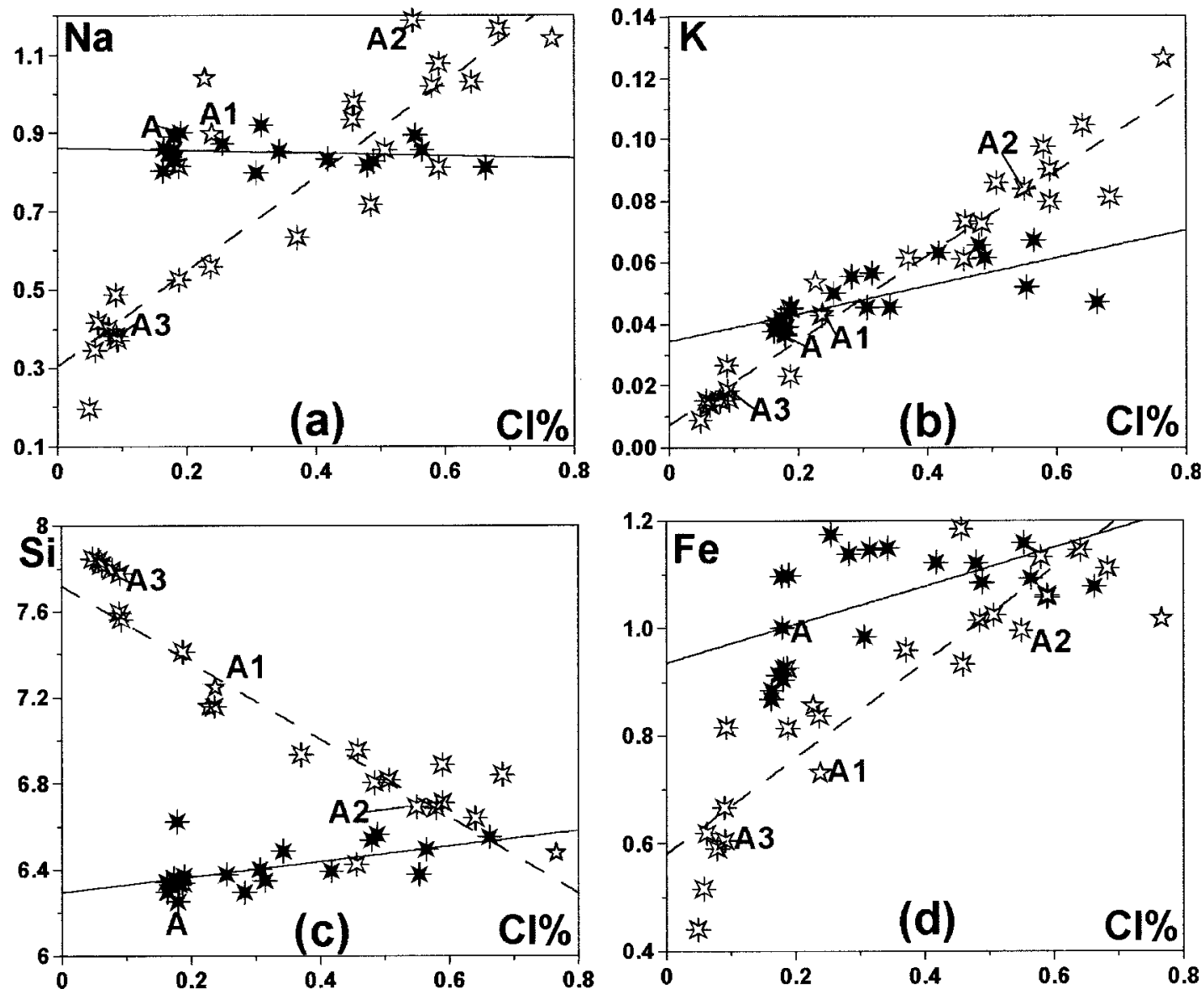

FIG. 8. Plot of Na, K, Si and Fe (apfu) versus chlorine concentration in wt.\% (in a, b, c and d, respectively) for amphiboles filling veins in the Cóbdar metabasalts. Key for symbols, and meaning of letters A, A1, A2 and A3, as in Figure 4. Arrows are joining similar points as the red arrows in Figure 3b. Dashes and continuous lines correspond, respectively, to regression lines for green and brown amphiboles. 


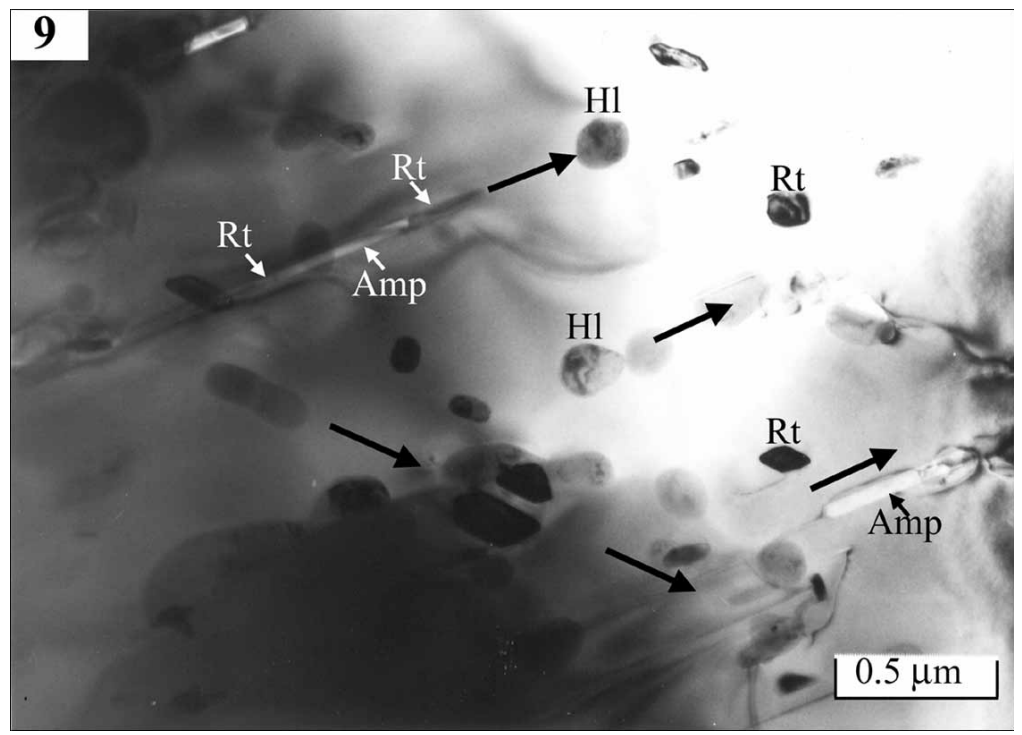

FIG. 9. Low-magnification TEM image showing the most common types of inclusion in brown amphibole: Rutile (Rt), $\mathrm{NaCl}(\mathrm{Hl})$ and actinolite (Amp), mostly oriented following preferential crystallographic directions in the amphibole host, which are marked by the arrows.

TABLE 3. REPRESENTATIVE AEM DATA ON BROWN AND GREEN AMPHIBOLES, COBDAR SUITE

\begin{tabular}{|c|c|c|c|c|c|c|}
\hline & \multicolumn{2}{|c|}{ Brown amphiboles } & \multicolumn{4}{|c|}{ Green amphiboles } \\
\hline & $\begin{array}{c}1 \\
\text { Ed }\end{array}$ & $\stackrel{2}{\mathrm{Prg}}$ & $\begin{array}{c}3 \\
\text { Mkt }\end{array}$ & $\begin{array}{c}4 \\
\mathrm{Mtm}\end{array}$ & $\begin{array}{l}5 \\
\mathrm{Tr}\end{array}$ & $\stackrel{6}{\text { Mhb }}$ \\
\hline $\begin{array}{l}\mathrm{Si} \text { apfu } \\
\mathrm{N}_{\mathrm{Al}} \\
\mathrm{vi}_{\mathrm{Al}} \\
\mathrm{Ti} \\
\mathrm{Fe}^{2+} \\
\mathrm{Fe}^{3+} \\
\mathrm{Mg} \\
\mathrm{Ca} \\
\mathrm{Na} \\
\mathrm{K} \\
\mathrm{O}\end{array}$ & $\begin{array}{r}6.97 \\
1.03 \\
0.36 \\
0.05 \\
1.02 \\
\\
3.28 \\
2.20 \\
0.73 \\
0.00 \\
23.00\end{array}$ & $\begin{array}{r}6.27 \\
1.73 \\
0.03 \\
0.44 \\
1.27 \\
\\
2.99 \\
2.05 \\
0.89 \\
0.05 \\
23.00\end{array}$ & $\begin{array}{r}6.51 \\
1.49 \\
0.84 \\
0.04 \\
0.67 \\
0.51 \\
2.67 \\
1.35 \\
1.84 \\
0.06 \\
23.00\end{array}$ & $\begin{array}{r}6.14 \\
1.86 \\
0.34 \\
0.08 \\
0.30 \\
1.00 \\
2.97 \\
1.78 \\
1.42 \\
0.10 \\
23.00\end{array}$ & $\begin{array}{r}7.50 \\
0.50 \\
0.00 \\
0.00 \\
0.00 \\
0.74 \\
3.20 \\
3.23 \\
0.00 \\
0.00 \\
23.00\end{array}$ & $\begin{array}{r}6.58 \\
0.50 \\
0.00 \\
0.00 \\
0.00 \\
0.80 \\
3.48 \\
3.59 \\
0.00 \\
0.00 \\
23.00\end{array}$ \\
\hline $\begin{array}{l}{ }^{B} \mathrm{Na} \\
{ }^{A} \mathrm{Na} \\
\mathrm{Fe}^{2+} / \\
\left(\mathrm{Fe}^{2+}+\mathrm{Mg}\right)\end{array}$ & $\begin{array}{l}0.09 \\
0.64 \\
\\
0.24\end{array}$ & $\begin{array}{l}0.22 \\
1.00 \\
0.28\end{array}$ & $\begin{array}{l}0.92 \\
0.94 \\
0.39\end{array}$ & $\begin{array}{l}0.52 \\
0.90 \\
0.31\end{array}$ & $\begin{array}{l}0.00 \\
0.00 \\
0.04\end{array}$ & $\begin{array}{l}0.00 \\
0.00 \\
0.00\end{array}$ \\
\hline
\end{tabular}

Symbols used: Ed: edenite, Prg: pargasite, Mkt: magnesiokatophorite, Mtm: magnesiotaramite, Tr: tremolite, Mhb: magnesiohomblende. apfu: atoms per formula unit.

nents of the inclusions as well as those of the host pargasite, given the extent of the area analyzed with respect to the size of the inclusions. This fact gives rise to high reported $\mathrm{Ti}$ and $\mathrm{Cl}$ contents, compared with the current composition of the host amphibole as deter- mined by AEM, in which these components are lacking (Table 3). The composition of the green amphiboles, established by EMPA and AEM analyses, show similar results. The AEM analyses reveal the presence of chlorine, which must be interpreted as an element incorporated in the structure of the amphibole.

\section{P-T Conditions of the Metamorphic Processes}

The calibrated geothermometer of Holland \& Blundy (1994) has been applied to some rare unaltered crystals of brown amphibole and their coexisting plagioclase in order to obtain a temperature estimate for the first assemblage of the veins. Likewise, this geothermometer has been applied to different pairs of green amphibole and albite in equilibrium to deduce the temperature of formation of the second assemblage of these veins. The amphibole composition of each pair and the proportion of the albite component in the plagioclase are indicated in Table 4, together with the variation in temperature for different pressures obtained for each pair.

The pairs I and II correspond to brown amphiboles (without transformation rims distinguishable by optical microscopy) and the plagioclase in contact with them. The amphibole composition is titanian pargasite in both pairs. The coexisting plagioclase varies between sodic oligoclase $\left(\mathrm{An}_{19}\right)$, which is the most calcic composition preserved, and albite $\left(\mathrm{An}_{6}\right)$, which is the most common plagioclase in these veins. 
The temperature calculated for the two pairs varies by about $200^{\circ} \mathrm{C}$ for the low-pressure limit. These differences in temperature, recorded in veins located in the same basaltic horizon, could be explained by a very high geothermal gradient, which is characteristic of oceanfloor metamorphism, or by changes in temperature during vein development. The pressure to be considered for this type of metamorphism acting on oceanic effusive rocks is very low and, therefore, the temperature values calculated with the geothermometer used would correspond to the maximum temperature calculated for each pair. For most of the pairs calculated, the maximum temperature obtained ranges between $820^{\circ}$ and the $879^{\circ} \mathrm{C}$ value corresponding to pair I; there are other pairs, however, with lower temperature, down to $660^{\circ} \mathrm{C}$ for pair II. This temperature represents, in turn, a minimum value for this pair, because the plagioclase contains some exsolved clinozoisite. Therefore, a temperature between $700^{\circ}$ and $880^{\circ} \mathrm{C}$ can be considered as the most probable range for the development of the brown amphibole in the veins, as well as for the first step of amphibole formation at the expense of the host basalts, which produced the same type of amphibole (Figs. 2ac, 3a).

A temperature higher than $700^{\circ} \mathrm{C}$ has been calculated for the first episode of ocean-floor metamorphism in gabbros recovered near the intersection of the Kane Fracture Zone and the Mid-Atlantic Ridge by Kelley \& Delaney (1987). In addition, Gaggero \& Cortesogno (1997) have calculated a temperature ranging between $800^{\circ}$ and $900^{\circ} \mathrm{C}$ for brown amphibole-plagioclase pairs from gabbros of the same oceanic zone, applying the Holland \& Blundy geothermometer. Moreover, Tribuzio et al. (2000) applied the same geothermometer to pargasite-plagioclase pairs of ophiolitic gabbros from the northern Apennines, which yielded equilibrium temperatures from $800^{\circ}$ to $950^{\circ} \mathrm{C}$. Nevertheless, in most oceanic and ophiolitic metabasic rocks, the upper temperature limit calculated for ocean-floor metamorphism is near $750^{\circ} \mathrm{C}$ (Mével 1988, Vanko \& Stakes 1991, Gillis \& Thompson 1993, Cortesogno et al. 1994).

The application of the Holland \& Blundy (1994) thermometer to green amphiboles and albite in equilibrium yields a temperature range clearly lower than for the brown amphibole at low pressure, as shown by pairs III and IV in Table 4. The temperature for these pairs increases with the increase in pressure, in contrast to the temperature evolution recorded for the brown amphibole-plagioclase pairs. Pairs III and IV have been calculated based on the equilibrium of barroisitic and taramitic amphiboles, respectively, with an albite of composition $\mathrm{An}_{4}$ in both cases.

In these veins, there are no minerals that allow us to quantitatively estimate the conditions of pressure. Nevertheless, the $f \mathrm{Al}\left(={ }^{\mathrm{VI}} \mathrm{Al} / \mathrm{Al}\right),{ }^{B} \mathrm{Na}$ and ${ }^{\mathrm{VI}} \mathrm{Al}$ values, which are parameters dependent of pressure conditions (Brown 1977, Smith 1988), are clearly greater in the green amphiboles than in the ocean-floor brown ones
(Tables 1 to 3 , Figs. 3 to 5), indicating that the second assemblage in the veins originated during the Alpine orogeny. Moreover, fAl, ${ }^{B} \mathrm{Na}$ and ${ }^{\mathrm{VI}} \mathrm{Al}$ values are similar in the green amphiboles filling these veins and in the host metabasalts, as well as in many other metabasic rocks of the Cóbdar outcrop, which were converted to amphibolite during the second event of Alpine metamorphism (Puga et al. 1989a, 2000).

These data suggest that these amphibole veins began their development during the ocean-floor stage of metamorphism and re-equilibrated, under the influence of a new metamorphic fluid richer in $\mathrm{CO}_{2}$ than the oceanic one, under conditions of the albite-epidote amphibolite facies, which affected these ophiolites after the less pervasive high-pressure event that locally developed the eclogite paragenesis. The pressure climax attained during the second metamorphic event in the Cóbdar region was approximately 8 kbar (Puga et al. 2000). This pressure would limit the maximum temperature attained in the veins, during the formation of the second assemblage, to values lower than $550^{\circ} \mathrm{C}$, according to the Holland \& Blundy (1994) geothermometer.

\section{Conclusions}

1. The minerals forming the described veins from Cóbdar ophiolitic metabasalts can be assigned to two generations of assemblages that belong to two different metamorphic events. The first assemblage, formed by pargasitic brown amphibole and sodic-calcic plagioclase, developed in a pre-Alpine stage of ocean-floor metamorphism. The second assemblage, comprising sodic-calcic and calcic green amphiboles, albite, clinozoisite, rutile and calcite, developed during the Alpine orogeny.

2. The first assemblage originated at temperatures ranging from $700^{\circ}$ to $880^{\circ} \mathrm{C}$ and very low pressures, under the influence of a chlorine-rich fluid responsible of the numerous $\mathrm{NaCl}$ micro-inclusions present in the brown amphiboles. This assemblage must have originated during a stage of ocean-floor metamorphism affecting the BOA, which was dated as Late Jurassic by Ar/Ar laser probe on these brown amphiboles.

3 . The second assemblage formed by the re-equilibration of the previous one, under the influence of a new $\mathrm{CO}_{2}$-rich metamorphic fluid and a marked increase in pressure and decrease in temperature with respect to the conditions of ocean-floor metamorphism. This second assemblage developed during the Alpine orogeny at conditions of the albite-epidote amphibolite facies, near $550^{\circ} \mathrm{C}$ and $8 \mathrm{kbar}$.

\section{ACKNOWLEDGEMENTS}

The authors are very grateful to A. Hynes, R.F. Martin (both of Montreal), and A. Willner (Bochum), whose corrections and suggestions notably improved the manuscript. Financial support from Project PB98-1334 
TABLE 4. TEMPERATURES OBTAINED BY APPLICATION OF THE HOLLAND \& BLUNDY (1994) GEOTHERMOMETER TO REPRESENTATIVE Amph-PI PAIRS

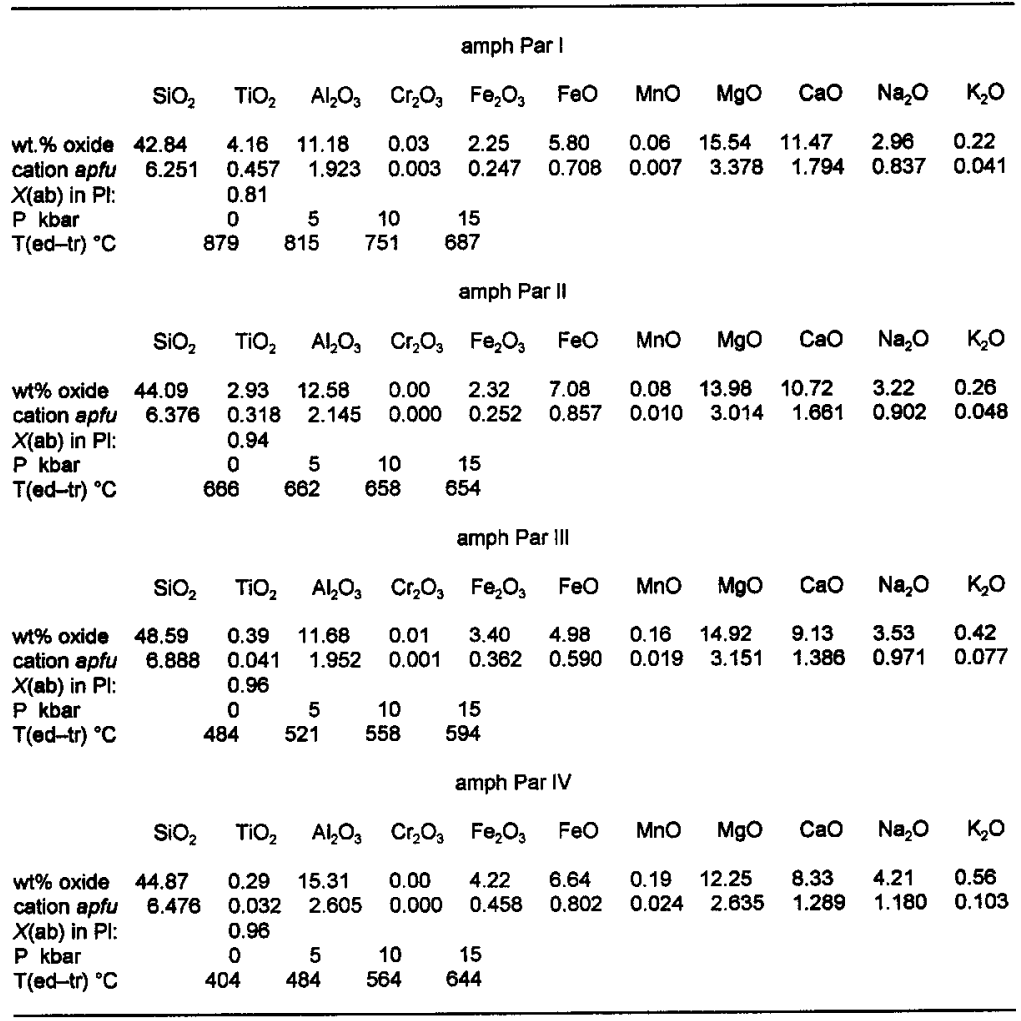

of the Spanish Ministry of Science and Tecnology, and the Research Group RNM 187 of the Junta de Andalucía are gratefully acknowledged. We are also grateful to A. Díaz Puga for the production of the photos and to Christine Laurin for polishing the English version of the text.

\section{REFERENCES}

Bodinier, J. L., Morten, L., Puga, E. \& Díaz de Federico, A. (1987): Geochemistry of metabasites from the NevadoFilabride Complex, Betic Cordilleras, Spain: relicts of a dismembered ophiolitic sequence. Lithos 20, 235-245.

Brown, E.H. (1977): The crossite content of Ca-amphiboles as a guide to pressure of metamorphism. J. Petrol. 18, 5372 .

Cortesogno, L., Gaggero, L. \& Molli, G. (1994): Ocean floor tectono-metamorphic evolution in the PiedmontLigurian Jurassic basin: a review. Soc. Geol. Ital., Mem. 48, 151-163.

\& LuCCHETTI, G. (1984): Ocean-floor metamorphism of the volcanic and sedimentary sequences in the
Northern Apennine Ophiolites: mineralogical and paragenetic features. Ofioliti 9(3), 363-400.

Deville, E., Fudral, S., Lagabrielle, Y., Marthaler, M. \& SARTORI, M. (1992): From oceanic closure to continental collision: a synthesis of the "Schistes lustrés" metamorphic complex of the Western Alps. Geol. Soc. Am., Bull. 104, 127-139.

Gaggero, L. \& Cortesogno, L. (1997): Metamorphic evolution of oceanic gabbros: recrystallization from subsolidus to hydrothermal conditions in the MARK area (ODP Leg 153). Lithos 40, 105-131.

Gillis, K.M. \& Thompson, G. (1993): Metabasalts from the Mid-Atlantic Ridge: new insights into hydrothermal systems in slow-spreading crust. Contrib. Mineral. Petrol. 113, 502-523.

\& Kelley, D. (1993): A view of the lower crustal component of hydrothermal systems at the Mid-Atlantic Ridge. J. Geophys. Res. 98, 19,597-19,619.

Gomez-Pugnaire, M.T., Ulmer, P. \& Lopez-SanchezVizcaino, V. (2000): Petrogenesis of the mafic igneous 
rocks of the Betic Cordilleras: a field, petrological and geochemical study. Contrib. Mineral. Petrol. 139, 436-457.

Hebeda, E.H., Boelrijk, N.A.I.M., Priem, H.N.A., VerDURMEN, E.A.T., VERSCHURE, R.H. \& SiMON, O.J. (1980): Excess radiogenic $\mathrm{Ar}$ and undisturbed $\mathrm{Rb}-\mathrm{Sr}$ systems in basic intrusives subjected to Alpine metamorphism in southeastern Spain. Earth Planet. Sci. Lett. 47, 81-90.

Holland, T. \& Blundy, J. (1994): Non-ideal interaction in calcic amphiboles and their bearing on amphiboleplagioclase thermometry. Contrib. Mineral. Petrol. 116, 433-447.

Ito, E. \& ANDERson, A.T., JR. (1983): Submarine metamorphism of gabbros from the Mid-Cayman Rise: petrographic and mineralogic constraint on hydrothermal processes at slow-spreading ridges. Contrib. Mineral. Petrol. 82, 371-388.

Kelley, D.S. \& Delaney, J.R. (1987): Two-phase separation and fracturing in mid-ocean ridge gabbros at temperatures greater than $700^{\circ}$ C. Earth Planet. Sci. Lett. 83, 53-66.

KreTZ, R. (1983): Symbols for rock-forming minerals. Am. Mineral. 68, 277-279.

Lagabrielle, Y., Polino, R., Auzende, J. M.., Blanchet, R., Caby, R., Fudral, S., Lemoine, M., Mével, C., OhnenStetter, M., Robert, D. \& Tricart, P. (1984): Les témoins d'une tectonique intraocéanique dans le domaine tethysien: analyse des rapports entre les ophiolites et leurs couvertures métasédimentaires dans la Zone Piémontaise des Alpes franco-italiennes. Ofioliti 9(1), 67-88.

LAIRD, J. \& AlBeE, A.L. (1981): Pressure, temperature, and time indicators in mafic schists: their application to reconstructing the polymetamorphic history of Vermont. Am. J. Sci. 281, 127-175.

Leake, B.E., Woolley, A.R., Arps, C.E.S., Birch, W.D., Gilbert, M.C., Grice, J.D., Hawthorne, F.C., KAto, A., Kisch, H.J., Krivovichev, V.G., Linthout, K., LAIRD, J., Maresch, W.V., Nickel, E.H., Rock, N.M.S., SCHUMACHER, J.C., SMith, D.C., STEPHENSON, N.C.N., UnGaReTti, L., Whittaker, E.J.W. \& Youzhi, G. (1997): Nomenclature of amphiboles. Report of the Subcommittee on Amphiboles of the International Mineralogical Association Commission on New Minerals and Mineral Names. Can. Mineral. 35, 219-246.

Lemoine, M., Marthaler, M., Caron, M., Sartori, M., Amaudric du Chaffaut, S., Dumont, T., Escher, A., Masson, H., Polino, R. \& Tricart, P. (1984): Découverte de foraminifères planctoniques du Crétacé supérieur dans les schistes lustrés du Queyras (Alpes occidentales). Conséquences paléogéographiques et tectoniques. C.R. Acad. Sci. Paris 299, sér. II, 727-732.

Mével, C. (1988): Metamorphism in oceanic layer 3, Gorringe Bank, Eastern Atlantic. Contrib. Mineral. Petrol. 100, 496509.
Morten, L., Bargossi, G.M., Martinez, J.M., Puga, E. \& DiAZ DE FEDERICO, A. (1987): Metagabbro and associated eclogites in the Lubrin area, Nevado-Filabride Complex, Spain. J. Metamorph. Geol. 5, 155-174.

Nieto, J.M. (1996): Petrología y Geoquímica de los Ortogneises del Complejo del Mulhacen, Cordilleras Béticas. Tesis Doctoral. Universidad de Granada, Spain.

, Puga, E., Díaz de Federico, A., SAnchez Rodriguez, D., Gebauer, E., Jagoutz, E. \& Monié, P. (1997): Petrological, geochemical and geochronological constraints on the geodynamic evolution from the Hercynian to Alpine orogeny in the Mulhacén Complex (Betic Cordilleras, Spain). Cuad. Geodin. Alpina Quat. 4, 85-86.

Portugal Ferreira, M., Ferreira, J.D., Puga, E. \& Diaz de FEDERICO, A. (1988): Geochronological contribution to the petrogenetic picture of the Betic Chain (SE Spain). II Congr. Geol. Esp. Com. 2, 55-58.

Prichard, H.M. \& CANN, J.R. (1982): Petrology and mineralogy of dredged gabbro from Gettysburg Bank, Eastern Atlantic. Contrib. Mineral. Petrol. 79, 46-55.

PugA, E. (1990): The Betic Ophiolitic association (southeastern Spain). Ofioliti 15(1), 97-117.

Diaz de Federico, A., BARgossi, G.M. \& Morten, L. (1989a): The Nevado-Filabride metaophiolitic association in the Cobdar region (Betic Cordillera, SE Spain): preservation of pillow structures and development of coronitic eclogites. Geodin. Acta 3(1), 17-36.

, Bodinier, J.L., Monié, P. \& Morten, L. (1991): The Betic ophiolitic eclogites (Nevado-Filabride Complex, SE Spain). In Second Eclogite Field Symp. Terra Nova Abstr., Suppl. 6, 9-10.

\& Demant, A. (1995): The eclogitized pillows of the Betic Ophiolitic Association: relics of the Tethys Ocean floor incorporated in the Alpine chain after subduction. Terra Nova 7, 31-43.

Fediukova, E., Bondi, M. \& Morten, L. (1989b): Petrology, geochemistry and metamorphic evolution of the ophiolitic eclogites and related rocks from the Sierra Nevada (Betic Cordilleras, southeastern Spain). Schweiz. Mineral. Petrogr. Mitt. 69, 435-455.

\& NIETO, J.M. (2002): Tectono-stratigraphic subdivision and petrological characterisation of the deepest complexes of the Betic Zone: a review. Geodin. Acta 15(1).

NiETo, J.M. \& DíAz DE Federico, A. (2000): Contrasting P-T paths in eclogites of the Betic Ophiolitic Association, Mulhacén Complex, southeastern Spain. Can. Mineral. 38, 1137-1161.

BODINIER, J.L. \& MORTEN,

L. (1999b): Petrology and metamorphic evolution of 
ultramafic rocks and dolerite dykes of the Betic Ophiolitic Association (Mulhacén Complex, SE Spain): evidence of eo-Alpine subduction following an ocean-floor metasomatic process. Lithos 49, 23-56.

Ruiz Cruz, M.D. \& Diaz de Federico, A. (1999a): Magnetite-silicate inclusions in olivine of ophiolitic metagabbros from the Mulhacén Complex, Betic Cordillera, southeastern Spain. Can. Mineral. 37, 1191-1209.

RAASE, P. (1974): Al and Ti content of hornblende, indicators of pressure and temperature in regional metamorphism. Contrib. Mineral. Petrol. 45, 231-236.

Robinson, P., SPeAr, F.S., Schumacher, J.C., Laird, J., KLEIN, K., Evans, B.W. \& Doolan, B.L. (1982): Phase relations of metamorphic amphiboles: natural occurrences and theory. Rev. Mineral. 9B, 2-11.

SCHUMACHER, J.C. (1997): The estimation of the proportion of ferric iron in the electron-microprobe analysis of amphiboles. Can. Mineral. 35, 238-246.

SMITH, D.C. (1988): A review of the peculiar mineralogy of the "Norwegian coesite-eclogite Province", with crystalchemical, petrological, geochemical and geodynamical notes and an extensive bibliography. In Eclogite and Eclogite-Facies Rocks (D.C. Smith, ed.). Elsevier, Amsterdam, Tnetherlands (1-206).

SPEAR, F.S. (1993): Metamorphic Phase Equilibria and Pressure-Temperature-Time Paths. Mineralogical Society of America, Washington, D.C.

Stakes, D., Mével, C., Cannat, M. \& Chaput, T. (1991): Metamorphic stratigraphy of Hole 735B. Proc. O.D.P., Scientific Results 118, 153-180.
\& VANKo, D.A. (1986): Multistage hydrothermal alteration of gabbroic rocks from the failed Mathematician Ridge. Earth Planet. Sci. Lett. 79, 75-92.

Tendero, J. A., Martin-Algarra, A., Puga, E. \& Diaz de FEDERICO, A. (1993): Lithostratigraphie des métasédiments de 1'association ophiolitique Nevado-Filabride (SE Espagne) et mise en évidence d'objets ankéritiques évoquant des foraminifères planctoniques du Crétacé: conséquences paléogéographiques. C.R. Acad. Sci. Paris 316, $1115-1122$

TribuZio, R., Tiepolo, M. \& ThiRlwall, M.F. (2000): Origin of titanian pargasite in gabbroic rocks from the Northern Apennine ophiolites (Italy): insights into the late-magmatic evolution of a MOR-type intrusive sequence. Earth Planet. Sci. Lett. 176, 281-293.

VANKO, D.A. (1986): High-chlorine amphiboles from oceanic rocks: product of highly-saline hydrothermal fluids? Am. Mineral. 71, 51-59.

\& STAKES, D.S. (1991): Fluids in oceanic layer.3. Evidence from veined rocks, hole 735B, Southwest Indian Ridge. Proc. O.D.P., Scientific Results 118, 181-215.

Volfinger, M., Robert, J-L.,Vielzeuf, D. \& Neiva, M.R. (1984): Structural control of the chlorine content of OHbearing silicates (micas and amphiboles). Geochim. Cosmochim. Acta 49, 37-48.

Received August 27, 2001, revised manuscript accepted February 5, 2002. 